\title{
Origins of DNA replication
}

\author{
Babatunde Ekundayo, Franziska Bleichert ${ }_{\mathbb{D}}$ * \\ Quantitative Biology, Friedrich Miescher Institute for Biomedical Research, Basel, Switzerland \\ * franziska.bleichert@yale.edu
}

\section{Abstract}

In all kingdoms of life, DNA is used to encode hereditary information. Propagation of the genetic material between generations requires timely and accurate duplication of DNA by semiconservative replication prior to cell division to ensure each daughter cell receives the full complement of chromosomes. DNA synthesis of daughter strands starts at discrete sites, termed replication origins, and proceeds in a bidirectional manner until all genomic DNA is replicated. Despite the fundamental nature of these events, organisms have evolved surprisingly divergent strategies that control replication onset. Here, we discuss commonalities and differences in replication origin organization and recognition in the three domains of life.

\section{f open Access}

Citation: Ekundayo B, Bleichert $F$ (2019) Origins of DNA replication. PLoS Genet 15(9): e1008320. https://doi.org/10.1371/journal.pgen.1008320

Published: September 12, 2019

Copyright: ๑ 2019 Ekundayo, Bleichert. This is an open access article distributed under the terms of the Creative Commons Attribution License, which permits unrestricted use, distribution, and reproduction in any medium, provided the original author and source are credited.

Funding: This work was supported by the Novartis Research Foundation and the European Research Council under the European Union's Horizon 2020 research and innovation program (ERC-STG757909). The funders had no role in the preparation of the article.

Competing interests: The authors have declared that no competing interests exist.

Wikipedia Version: https://en.wikipedia.org/wiki/ origins_of_dna_replication.

\section{Introduction}

In the second half of the 19th century, Gregor Mendel's pioneering work on the inheritance of traits in pea plants suggested that specific "factors" (today established as genes) are responsible for transferring organismal traits between generations [1]. Although proteins were initially assumed to serve as the hereditary material, Avery, MacLeod and McCarty established a century later DNA, which had been discovered by Friedrich Miescher, as the carrier of genetic information [2]. These findings paved the way for research uncovering the chemical nature of DNA and the rules for encoding genetic information, and ultimately led to the proposal of the double-helical structure of DNA by Watson and Crick [3]. This three-dimensional model of DNA illuminated potential mechanisms by which the genetic information could be copied in a semiconservative manner prior to cell division, a hypothesis that was later experimentally supported by Meselson and Stahl using isotope incorporation to distinguish parental from newly synthesized DNA [4][5]. The subsequent isolation of DNA polymerases, the enzymes that catalyze the synthesis of new DNA strands, by Kornberg and colleagues pioneered the identification of many different components of the biological DNA replication machinery, first in the bacterial model organism E. coli, but later also in eukaryotic life forms [6].

A key prerequisite for DNA replication is that it must occur with extremely high fidelity and efficiency exactly once per cell cycle to prevent the accumulation of genetic alterations with potentially deleterious consequences for cell survival and organismal viability [7]. Incomplete, erroneous, or untimely DNA replication events can give rise to mutations, chromosomal polyploidy or aneuploidy, and gene copy number variations, each of which in turn can lead to 
diseases, including cancer [8][9]. To ensure complete and accurate duplication of the entire genome and the correct flow of genetic information to progeny cells, all DNA replication events are not only tightly regulated with cell cycle cues but are also coordinated with other cellular events such as transcription and DNA repair [10][11][12].

DNA replication is divided into different stages (Fig 1). During initiation, the replication machineries-termed replisomes-are assembled on DNA in a bidirectional fashion. These assembly loci constitute the start sites of DNA replication or replication origins. In the elongation phase, replisomes travel in opposite directions with the replication forks, unwinding the DNA helix and synthesizing complementary daughter DNA strands using both parental strands as templates. Once replication is complete, specific termination events lead to the disassembly of replisomes. As long as the entire genome is duplicated before cell division, one might assume that the location of replication start sites does not matter; yet, it has been shown that many organisms use preferred genomic regions as origins [13][14]. The necessity to regulate origin location likely arises from the need to coordinate DNA replication with other processes that act on the shared chromatin template to avoid DNA strand breaks and DNA damage [8][12][15][16][17][18][19].

\section{The replicon model}

More than five decades ago, Jacob, Brenner, and Cuzin proposed the replicon hypothesis to explain the regulation of chromosomal DNA synthesis in E. coli [20]. The model postulates that a diffusible, trans-acting factor, a so-called initiator, interacts with a cis-acting DNA element, the replicator, to promote replication onset at a nearby origin (Fig $1 \mathrm{~A}, i)$. Once bound to replicators, initiators (often with the help of co-loader proteins) deposit replicative helicases onto DNA, which subsequently drive the recruitment of additional replisome components and the assembly of the entire replication machinery (Fig $1 \mathrm{~A}, \boldsymbol{i i}$ ). The replicator thereby specifies the location of replication initiation events, and the chromosome region that is replicated from a single origin or initiation event is defined as the replicon.

A fundamental feature of the replicon hypothesis is that it relies on positive regulation to control DNA replication onset, which can explain many experimental observations in bacterial and phage systems [20]. For example, it accounts for the failure of extrachromosomal DNAs without origins to replicate when introduced into host cells. It further rationalizes plasmid incompatibilities in E. coli, where certain plasmids destabilize each other's inheritance due to competition for the same molecular initiation machinery [21]. By contrast, a model of negative regulation (analogous to the replicon-operator model for transcription) fails to explain the above findings [20]. Nonetheless, research subsequent to Jacob's, Brenner's and Cuzin's proposal of the replicon model has discovered many additional layers of replication control in bacteria and eukaryotes that comprise both positive and negative regulatory elements, highlighting both the complexity and the importance of restricting DNA replication temporally and spatially [22][23][24].

The concept of the replicator as a genetic entity has proven very useful in the quest to identify replicator DNA sequences and initiator proteins in prokaryotes, and to some extent also in eukaryotes, although the organization and complexity of replicators differ considerably between the domains of life (for reviews, see [25][26]). While bacterial genomes typically contain a single replicator that is specified by consensus DNA sequence elements and that controls replication of the entire chromosome (Fig 1A), most eukaryotic replicators-with the exception of budding yeast-are not defined at the level of DNA sequence; instead, they appear to be specified combinatorially by local DNA structural and chromatin cues [27][28][29][30] [31][32] [33][34][35][36]. Eukaryotic chromosomes are also much larger than their bacterial 
A

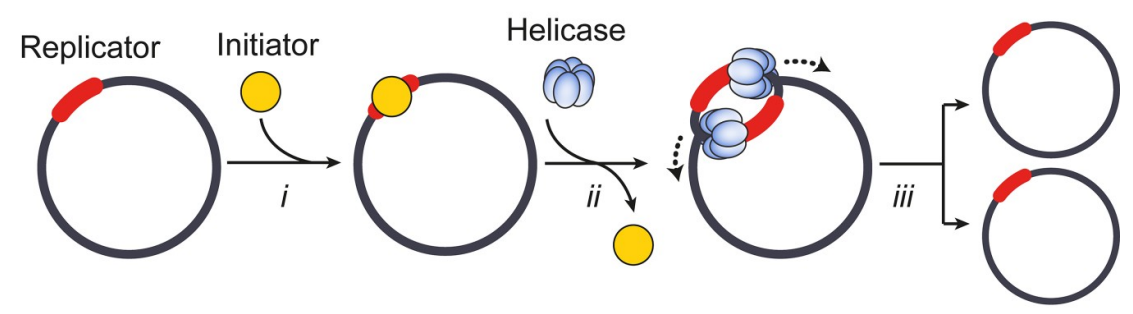

B

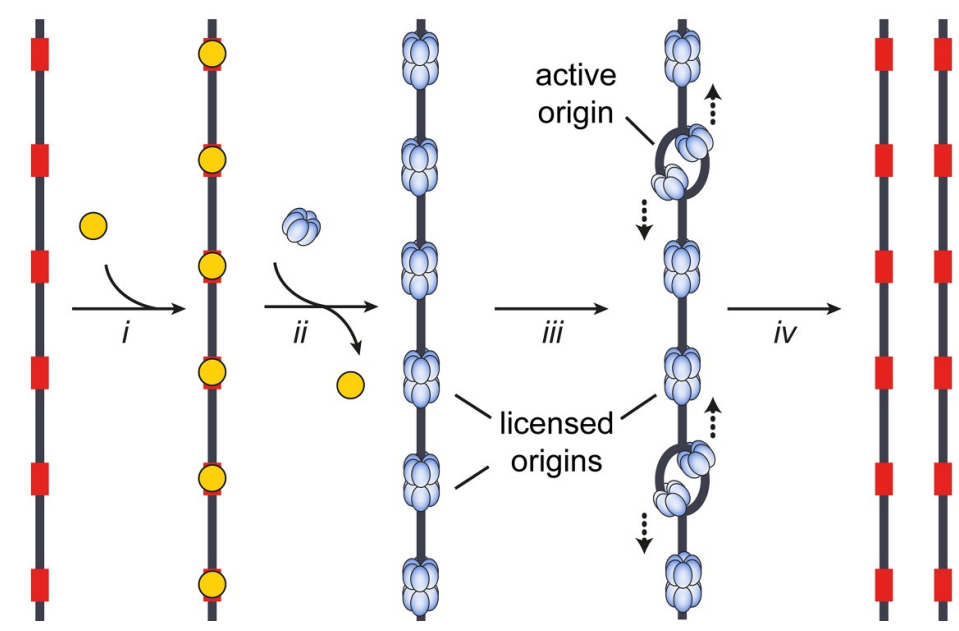

Fig 1. Models for bacterial (A) and eukaryotic (B) DNA replication initiation. A) Circular bacterial chromosomes contain a cis-acting element, the replicator, that is located at or near replication origins. $i$ ) The replicator recruits initiator proteins in a DNA sequence-specific manner, which results in melting of the DNA helix and loading of the replicative helicase onto each of the single DNA strands (ii). iii) Assembled replisomes bidirectionally replicate DNA to yield two copies of the bacterial chromosome. B) Linear eukaryotic chromosomes contain many replication origins. Initiator binding (i) facilitates replicative helicase loading (ii) onto duplex DNA to license origins. iii) A subset of loaded helicases is activated for replisome assembly. Replication proceeds bidirectionally from origins and terminates when replication forks from adjacent active origins meet $(i v)$.

https://doi.org/10.1371/journal.pgen.1008320.g001

counterparts, raising the need for initiating DNA synthesis from many origins simultaneously to ensure timely replication of the entire genome (Fig 1B). Additionally, many more replicative helicases are loaded than activated to initiate replication in a given cell cycle (Fig 1B). The context-driven definition of replicators and selection of origins suggests a relaxed replicon model in eukaryotic systems that allows for flexibility in the DNA replication program [25]. Although replicators and origins can be spaced physically apart on chromosomes, they often co-localize or are located in close proximity; for simplicity, we will thus refer to both elements as 'origins' throughout this review. Taken together, the discovery and isolation of origin sequences in various organisms represents a significant milestone towards gaining mechanistic understanding of replication initiation. In addition, these accomplishments had profound biotechnological implications for the development of shuttle vectors that can be propagated in bacterial, yeast, and mammalian cells [37][38][39].

\section{Bacterial replication origins}

Most bacterial chromosomes are circular and contain a single origin of chromosomal replication (oriC). Bacterial oriC regions are surprisingly diverse in size (ranging from $250 \mathrm{bp}$ to 2 
kbp), sequence, and organization [41][42]; nonetheless, their ability to drive replication onset typically depends on sequence-specific readout of consensus DNA elements by the bacterial initiator, a protein called DnaA [43][44][45][46]. Origins in bacteria are either continuous or bipartite and contain three functional elements that control origin activity: conserved DNA repeats that are specifically recognized by DnaA (called DnaA-boxes), an AT-rich DNA unwinding element (DUE), and binding sites for proteins that help regulate replication initiation (for reviews, see [13][47][48]; Fig 2A). Interactions of DnaA both with the doublestranded (ds) DnaA-box regions and with single-stranded (ss) DNA in the DUE are important for origin activation and are mediated by different domains in the initiator protein: a helixturn-helix (HTH) DNA binding element and an ATPase associated with various cellular activities (AAA+) domain, respectively (Fig 2B) [49][50][51][52][53][54][55][56]. While the sequence, number, and arrangement of origin-associated DnaA-boxes vary throughout the bacterial kingdom, their specific positioning and spacing in a given species are critical for oriC function and for productive initiation complex formation [41][42][57][58][59][60][61].

Among bacteria, E. coli is a particularly powerful model system to study the organization, recognition, and activation mechanism of replication origins. E. coli oriC comprises an approximately $260 \mathrm{bp}$ region containing four types of initiator binding elements that differ in their affinities for DnaA and their dependencies on the co-factor ATP (Fig 2A). DnaA-boxes R1, R2, and R4 constitute high-affinity sites that are bound by the HTH domain of DnaA irrespective of the nucleotide-binding state of the initiator [43][62][63][64][65][66]. By contrast, the I, $\tau$, and C-sites, which are interspersed between the R-sites, are low-affinity DnaA-boxes and associate preferentially with ATP-bound DnaA, although ADP-DnaA can substitute for ATP-DnaA under certain conditions [67][68][69][60]. Binding of the HTH domains to the high- and low-affinity DnaA recognition elements promotes ATP-dependent higher-order oligomerization of DnaA's AAA+ modules into a right-handed filament that wraps duplex DNA around its outer surface, thereby generating superhelical torsion that facilitates melting of the adjacent AT-rich DUE (Fig 2C) [49][70][71][72]. DNA strand separation is additionally aided by direct interactions of DnaA's AAA + ATPase domain with triplet repeats, so-called DnaA-trios, in the proximal DUE region [73]. The engagement of single-stranded trinucleotide segments by the initiator filament stretches DNA and stabilizes the initiation bubble by preventing reannealing [53]. The DnaA-trio origin element is conserved in many bacterial species, indicating it is a key element for origin function [73]. After melting, the DUE provides an entry site for the E. coli replicative helicase DnaB, which is deposited onto each of the single DNA strands by its loader protein DnaC.

Although the different DNA binding activities of DnaA have been extensively studied biochemically and various apo, ssDNA-, or dsDNA-bound structures have been determined [52] [53][54][71], the exact architecture of the higher-order DnaA-oriC initiation assembly remains unclear. Two models have been proposed to explain the organization of essential origin elements and DnaA-mediated oriC melting. The two-state model assumes a continuous DnaA filament that switches from a dsDNA binding mode (the organizing complex) to an ssDNA binding mode in the DUE (the melting complex) (Fig 2C, left panel) [71][74]. By contrast, in the loop-back model, the DNA is sharply bent in oriC and folds back onto the initiator filament so that DnaA protomers simultaneously engage double- and single-stranded DNA regions (Fig 2C, right panel) [75]. Elucidating how exactly oriC DNA is organized by DnaA remains thus an important task for future studies. Insights into initiation complex architecture will help explain not only how origin DNA is melted, but also how a replicative helicase is loaded directionally onto each of the exposed single DNA strands in the unwound DUE, and how these events are aided by interactions of the helicase with the initiator and specific loader proteins. 
A

E. coli oriC

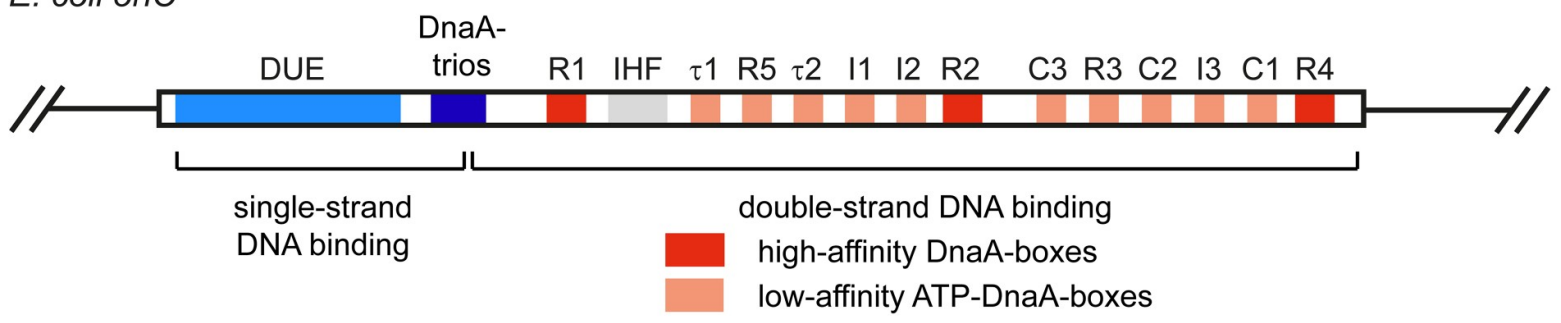

Thermotoga maritima oriC

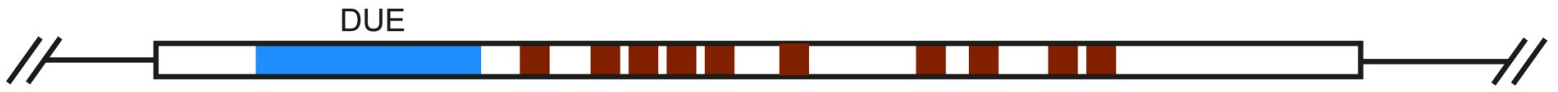

Helicobacter pylori oriC

DnaA-boxes

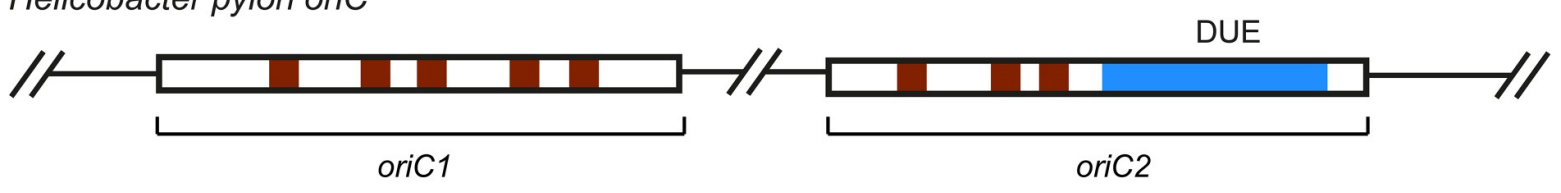

B

C DnaA

Two-state model

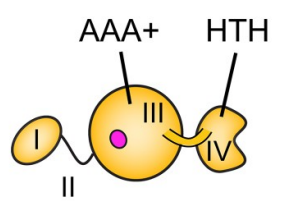
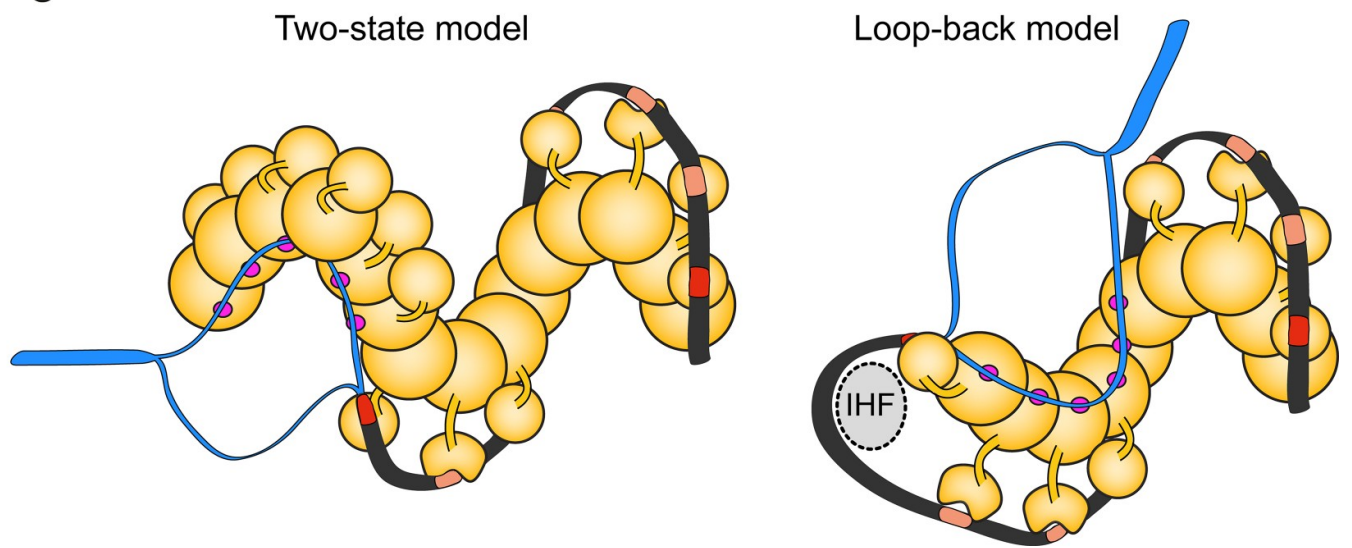

Fig 2. Origin organization and recognition in bacteria. A) Schematic of the architecture of E. coli origin oriC, Thermotoga maritima oriC, and the bipartite origin in Helicobacter pylori. The DUE is flanked on one side by several high- and weak-affinity DnaA-boxes as indicated for E. coli oriC. B) Domain organization of the E. coli initiator DnaA. The magenta circle indicates the single-strand DNA binding site. C) Models for origin recognition and melting by DnaA. In the two-state model (left panel), the DnaA protomers transition from a dsDNA binding mode (mediated by the HTH-domains recognizing DnaA-boxes) to an ssDNA binding mode (mediated by the AAA+ domains). In the loop-back model, the DNA is sharply bent backwards onto the DnaA filament (facilitated by the regulatory protein IHF [40]) so that a single protomer binds both duplex and single-stranded regions. In either instance, the DnaA filament melts the DNA duplex and stabilizes the initiation bubble prior to loading of the replicative helicase (DnaB in E. coli). HTH-helix-turn-helix domain, DUE-DNA unwinding element, IHF-integration host factor.

https://doi.org/10.1371/journal.pgen.1008320.g002

\section{Archaeal replication origins}

Archaeal replication origins share some but not all of the organizational features of bacterial oriC. Unlike bacteria, archaea often initiate replication from multiple origins per chromosome (one to four have been reported) [76][77][78][79][80][81][82] [83][42]; yet, archaeal origins also bear specialized sequence regions that control origin function (for recent reviews, see [84] 
[85][86]). These elements include both DNA sequence-specific origin recognition boxes (ORBs or miniORBs) and an AT-rich DUE that is flanked by one or several ORB regions [82] [87]. ORB elements display a considerable degree of diversity in terms of their number, arrangement, and sequence, both among different archaeal species and among different origins within in a single species [77][82][88]. An additional degree of complexity is introduced by the initiator, Orc1/Cdc6 in archaea, which binds to ORB regions. Archaeal genomes typically encode multiple paralogs of Orc1/Cdc6 that vary substantially in their affinities for distinct ORB elements and that differentially contribute to origin activities [82][89][90][91]. In Sulfolobus solfataricus, for example, three chromosomal origins have been mapped (oriC1, oriC2, and oriC3; Fig 3A), and biochemical studies have revealed complex binding patterns of initiators at these sites (Fig 3B) [82] [83] [92] [93]. The cognate initiator for oriC1 is Orc1-1, which associates with several ORBs at this origin [82][90]. OriC2 and oriC3 are bound by both Orc1-1 and Orc1-3 [82][90][93]. Conversely, a third paralog, Orc1-2, footprints at all three origins but has been postulated to negatively regulate replication initiation [82][93]. Additionally, the WhiP protein, an initiator unrelated to Orc1/Cdc6, has been shown to bind all origins as well and to drive origin activity of oriC3 in the closely related Sulfolobus islandicus [90][92]. Because archaeal origins often contain several adjacent ORB elements, multiple Orc1/Cdc6 paralogs can be simultaneously recruited to an origin and oligomerize in some instances [91] [94]; however, in contrast to bacterial DnaA, formation of a higher-order initiator assembly does not appear to be a general prerequisite for origin function in the archaeal domain.

Structural studies have provided insights into how archaeal Orc1/Cdc6 recognizes ORB elements and remodels origin DNA [94][95]. Orc1/Cdc6 paralogs are two-domain proteins and are composed of a AAA + ATPase module fused to a C-terminal winged-helix fold (Fig 3C) [96][97][98]. DNA-complexed structures of Orc1/Cdc6 revealed that ORBs are bound by an Orc1/Cdc6 monomer despite the presence of inverted repeat sequences within ORB elements [94] [95]. Both the ATPase and winged-helix regions interact with the DNA duplex but contact the palindromic ORB repeat sequence asymmetrically, which orients Orc1/Cdc6 in a specific direction on the repeat [94] [95]. Interestingly, the DUE-flanking ORB or miniORB elements often have opposite polarities [77][82][91][99][100], which predicts that the AAA+ lid subdomains and the winged-helix domains of Orc1/Cdc6 are positioned on either side of the DUE in a manner where they face each other (Fig 3B, bottom panel) [94][95]. Since both regions of Orc1/Cdc6 associate with the minichromosome maintenance (MCM) replicative helicase [101][102], this specific arrangement of ORB elements and Orc1/Cdc6 is likely important for loading two MCM complexes symmetrically onto the DUE (Fig 3B) [82]. Surprisingly, while the ORB DNA sequence determines the directionality of Orc1/Cdc6 binding, the initiator makes relatively few sequence-specific contacts with DNA [94][95]. However, Orc1/Cdc6 underwinds and bends DNA, suggesting that it relies on a mix of both DNA sequence and context-dependent DNA structural features to recognize origins [94][95][103]. Notably, base pairing is maintained in the distorted DNA duplex upon Orc1/Cdc6 binding in the crystal structures [94][95], whereas biochemical studies have yielded contradictory findings as to whether archaeal initiators can melt DNA similarly to bacterial DnaA [90][91][104]. Although the evolutionary kinship of archaeal and eukaryotic initiators and replicative helicases indicates that archaeal MCM is likely loaded onto duplex DNA (see next section), the temporal order of origin melting and helicase loading, as well as the mechanism for origin DNA melting, in archaeal systems remains therefore to be clearly established. Likewise, how exactly the MCM helicase is loaded onto DNA needs to be addressed in future studies. 
A

B

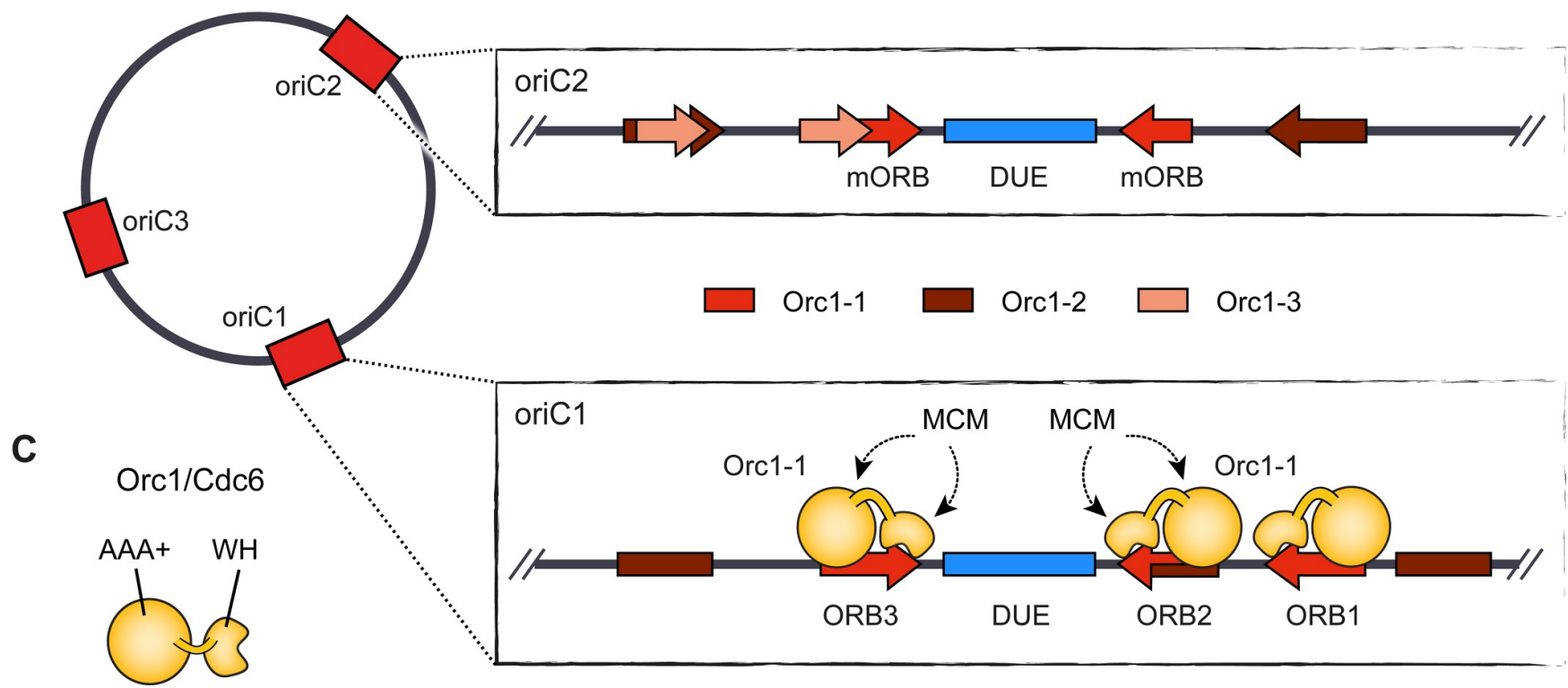

Fig 3. Origin organization and recognition in archaea. A) The circular chromosome of Sulfolobus solfataricus contains three different origins. B) Arrangement of initiator binding sites at two S. solfataricus origins, oriC1 and oriC2. Orc1-1 association with ORB elements is shown for oriC1. Recognition elements for additional Orc1/Cdc6 paralogs are also indicated, while WhiP binding sites have been omitted. C) Domain architecture of archaeal Orc1/Cdc6 paralogs. The orientation of ORB elements at origins leads to directional binding of Orc1/Cdc6 and MCM loading in between opposing ORBs (in B). (m)ORB-(mini-)origin recognition box, DUE-DNA unwinding element, WH-winged-helix domain.

https://doi.org/10.1371/journal.pgen.1008320.g003

\section{Eukaryotic replication origins}

Origin organization, specification, and activation in eukaryotes are more complex than in bacterial or archaeal kingdoms and significantly deviate from the paradigm established for prokaryotic replication initiation. The large genome sizes of eukaryotic cells, which range from 12 $\mathrm{Mbp}$ in S. cerevisiae to $3 \mathrm{Gbp}$ in humans, necessitates that DNA replication starts at several hundred (in budding yeast) to tens of thousands (in humans) origins to complete DNA replication of all chromosomes during each cell cycle (for recent reviews, see [32][23]). With the exception of S. cerevisiae and related Saccharomycotina species, eukaryotic origins do not contain consensus DNA sequence elements but their location is influenced by contextual cues such as local DNA topology, DNA structural features, and chromatin environment [25][31] [33]. Nonetheless, eukaryotic origin function still relies on a conserved initiator protein complex to load replicative helicases onto DNA during the late M and G1 phases of the cell cycle, a step known as origin licensing (Fig 1B). [107] In contrast to their bacterial counterparts, replicative helicases in eukaryotes are loaded onto origin duplex DNA in an inactive, double-hexameric form and only a subset of them (10-20\% in mammalian cells) is activated during any given S phase, events that are referred to as origin firing (Fig 1B) [108][109][110]. The location of active eukaryotic origins is therefore determined on at least two different levels, origin licensing to mark all potential origins, and origin firing to select a subset that permits assembly of the replication machinery and initiation of DNA synthesis. The extra licensed origins serve as backup and are activated only upon slowing or stalling of nearby replication forks, ensuring that DNA replication can be completed when cells encounter replication stress [111][112]. Together, the excess of licensed origins and the tight cell cycle control of origin licensing and firing embody two important strategies to prevent under- and overreplication and to maintain the integrity of eukaryotic genomes. 
Early studies in S. cerevisiae indicated that replication origins in eukaryotes might be recognized in a DNA-sequence-specific manner analogously to those in prokaryotes. In budding yeast, the search for genetic replicators lead to the identification of autonomously replicating sequences (ARS) that support efficient DNA replication initiation of extrachromosomal DNA [113][114][115]. These ARS regions are approximately $100-200$ bp long and exhibit a multipartite organization, containing A, B1, B2, and sometimes B3 elements that together are essential for origin function (Fig 4) [116][117]. The A element encompasses the conserved $11 \mathrm{bp}$ ARS consensus sequence (ACS) [118][119], which, in conjunction with the B1 element, constitutes the primary binding site for the heterohexameric origin recognition complex (ORC), the eukaryotic replication initiator [120][121][122][123]. Within ORC, five subunits are predicated on conserved AAA + ATPase and winged-helix folds and co-assemble into a pentameric ring that encircles DNA (Fig 4) [123][124][125]. In budding yeast ORC, DNA binding elements in the ATPase and winged-helix domains, as well as adjacent basic patch regions in some of the ORC subunits, are positioned in the central pore of the ORC ring such that they aid the DNA-sequence-specific recognition of the ACS in an ATP-dependent manner [123] [126]. By contrast, the roles of the B2 and B3 elements are less clear. The B2 region is similar to the ACS in sequence and has been suggested to function as a second ORC binding site under certain conditions, or as a binding site for the replicative helicase core [127][128][129][130] [131]. Conversely, the B3 element recruits the transcription factor Abf1, albeit B3 is not found at all budding yeast origins and Abf1 binding does not appear to be strictly essential for origin function [116][132][133].

Origin recognition in eukaryotes other than S. cerevisiae or its close relatives does not conform to the sequence-specific readout of conserved origin DNA elements. Pursuits to isolate specific chromosomal replicator sequences more generally in eukaryotic species, either genetically or by genome-wide mapping of initiator binding or replication start sites, have failed to identify clear consensus sequences at origins [134][135][136][137][138][139][140][141][142] [143][144][145]. Thus, sequence-specific DNA-initiator interactions in budding yeast signify a specialized mode for origin recognition in this system rather than an archetypal mode for origin specification across the eukaryotic domain. Nonetheless, DNA replication does initiate at discrete sites that are not randomly distributed across eukaryotic genomes, arguing that alternative means determine the chromosomal location of origins in these systems. These mechanisms involve a complex interplay between DNA accessibility, nucleotide sequence skew (both AT-richness and CpG islands have been linked to origins), nucleosome positioning, epigenetic features, DNA topology and certain DNA structural features (e.g., G4 motifs), as well as regulatory proteins and transcriptional interference [13][14][30][31][33][146][147][139][148]. Importantly, origin properties vary not only between different origins in an organism and among species, but some can also change during development and cell differentiation. The chorion locus in Drosophila follicle cells constitutes a well-established example for spatial and developmental control of initiation events. This region undergoes DNA-replication-dependent gene amplification at a defined stage during oogenesis and relies on the timely and specific activation of chorion origins, which in turn is regulated by origin-specific cis-elements and several protein factors, including the Myb complex, E2F1, and E2F2 [149][150][151][152] [153]. This combinatorial specification and multifactorial regulation of metazoan origins has complicated the identification of unifying features that determine the location of replication start sites across eukaryotes more generally.

To facilitate replication initiation, ORC assemblies from various species have evolved specialized auxiliary domains that are thought to aid initiator targeting to chromosomal origins or chromosomes in general (Fig 4). For example, the Orc4 subunit in S. pombe ORC contains several AT-hooks that preferentially bind AT-rich DNA [154], while in metazoan ORC the 


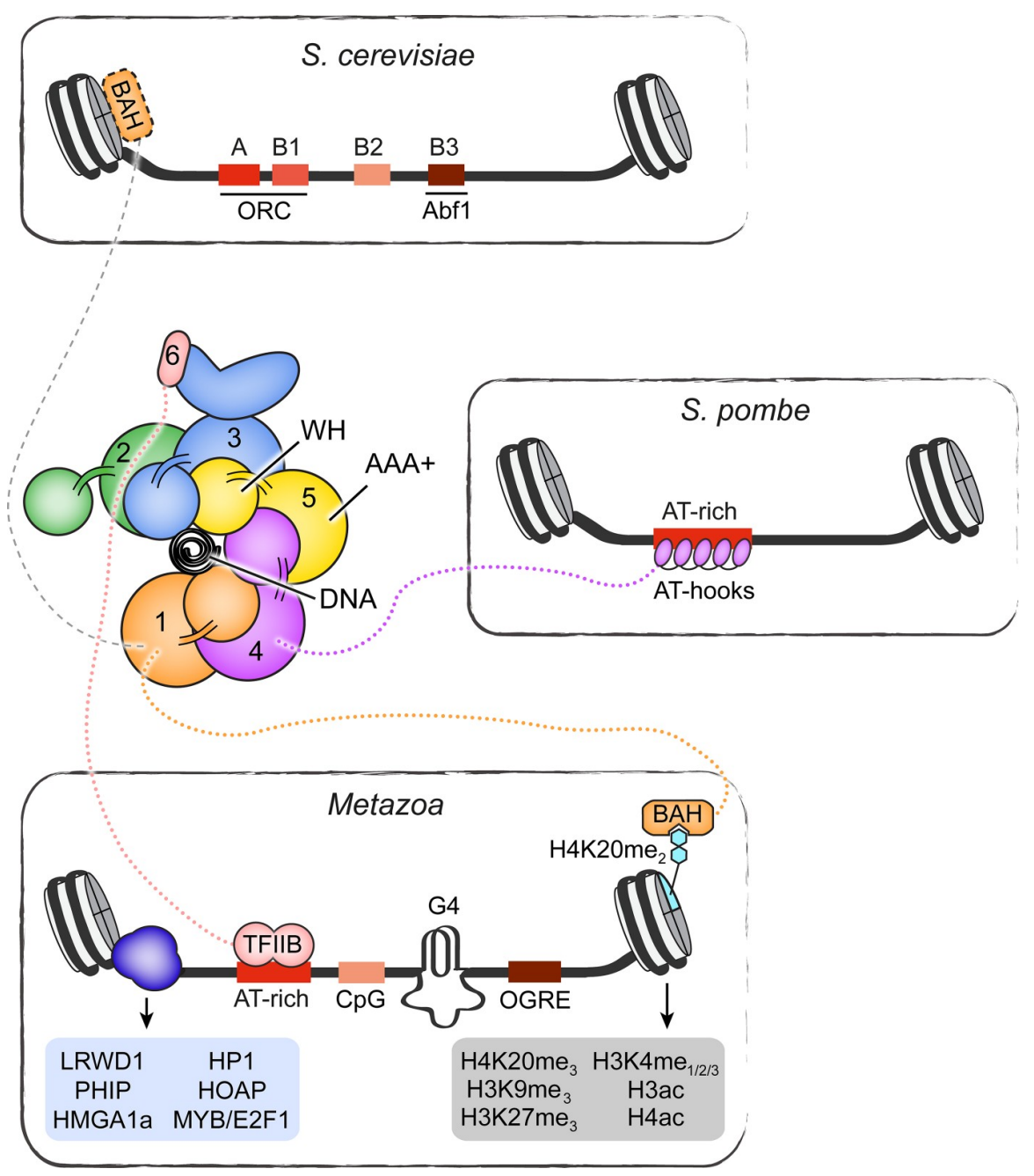

Fig 4. Origin organization and recognition in eukaryotes. Specific DNA elements and epigenetic features involved in ORC recruitment and origin function are summarized for S. cerevisiae, S. pombe, and metazoan origins. A schematic of the ORC architecture is also shown, highlighting the arrangement of the AAA+ and winged-helix domains into a pentameric ring that encircles origin DNA. Ancillary domains of several ORC subunits involved in targeting ORC to chromosomes are included. Other regions in ORC subunits may also be involved in initiator recruitment, either by directly or indirectly associating with partner proteins. A few examples are listed. Note that the BAH domain in S. cerevisiae Orc1 binds nucleosomes [105] but does not recognize H4K20me2 [106]. BAH-bromoadjacent homology domain, WH-winged-helix domain, TFIIB-transcription factor II B-like domain in Orc6, G4 -G quadruplex, OGRE-origin G-rich repeated element.

https://doi.org/10.1371/journal.pgen.1008320.g004

TFIIB-like domain of Orc6 is thought to perform a similar function [155]. Metazoan Orc1 proteins also harbor a bromo-adjacent homology (BAH) domain that interacts with H4K20me2-nucleosomes [106]. Particularly in mammalian cells, H4K20 methylation has been reported to be required for efficient replication initiation, and the Orc1-BAH domain facilitates ORC association with chromosomes and Epstein-Barr virus origin-dependent replication [156][157] [158][159][160]. Therefore, it is intriguing to speculate that both observations are mechanistically linked at least in a subset of metazoa, but this possibility needs to be further explored in future studies. In addition to the recognition of certain DNA or epigenetic features, ORC also associates directly or indirectly with several partner proteins that could aid initiator recruitment, including LRWD1, PHIP (or DCAF14), HMGA1a, among others (Fig 4) [29][161][162] 
[163][164][165][166][167]. Interestingly, Drosophila ORC, like its budding yeast counterpart, bends DNA and negative supercoiling has been reported to enhance DNA binding of this complex, suggesting that DNA topology and malleability might influence the location of ORC binding sites across metazoan genomes [27][123][168][169][170]. A molecular understanding for how ORC's DNA binding regions might support the readout of structural properties of the DNA duplex in metazoans rather than of specific DNA sequences as in S. cerevisiae awaits high-resolution structural information of DNA-bound metazoan initiator assemblies. Likewise, how different epigenetic factors contribute to initiator recruitment in metazoan systems is poorly defined and is an important question that needs to be addressed in more detail.

Once recruited to origins, ORC and its co-factors Cdc6 and Cdt1 drive the deposition of the minichromosome maintenance 2-7 (Mcm2-7) complex onto DNA (for reviews see [107] [171]). Like the archaeal replicative helicase core, $\mathrm{Mcm} 2-7$ is loaded as a head-to-head double hexamer onto DNA to license origins (Fig 1B) [108][109][110]. In S-phase, Dbf4-dependent kinase (DDK) and cyclin-dependent kinase (CDK) phosphorylate several Mcm2-7 subunits and additional initiation factors to promote the recruitment of the helicase co-activators Cdc45 and GINS, DNA melting, and ultimately bidirectional replisome assembly at a subset of the licensed origins (Fig 1B) [172][24]. In both yeast and metazoans, origins are free or depleted of nucleosomes, a property that is crucial for Mcm2-7 loading, indicating that chromatin state at origins regulates not only initiator recruitment but also helicase loading [140] [173][174][175][176][177]. A permissive chromatin environment is further important for origin activation and has been implicated in regulating both origin efficiency and the timing of origin firing. Euchromatic origins typically contain active chromatin marks, replicate early, and are more efficient than late-replicating, heterochromatic origins, which conversely are characterized by repressive marks [23][175][178]. Not surprisingly, several chromatin remodelers and chromatin-modifying enzymes have been found to associate with origins and certain initiation factors [179][180], but how their activities impact different replication initiation events remains largely obscure. Remarkably, cis-acting "early replication control elements" (ERCEs) have recently also been identified to help regulate replication timing and to influence 3D genome architecture in mammalian cells [181]. Understanding the molecular and biochemical mechanisms that orchestrate this complex interplay between $3 \mathrm{D}$ genome organization, local and higher-order chromatin structure, and replication initiation is an exciting topic for further studies.

Why have metazoan replication origins diverged from the DNA sequence-specific recognition paradigm that determines replication start sites in prokaryotes and budding yeast? Observations that metazoan origins often co-localize with promoter regions in Drosophila and mammalian cells and that replication-transcription conflicts due to collisions of the underlying molecular machineries can lead to DNA damage suggest that proper coordination of transcription and replication is important for maintaining genome stability [135][137][139][142] [182][16][17][19]. Recent findings also point to a more direct role of transcription in influencing the location of origins, either by inhibiting $\mathrm{Mcm} 2-7$ loading or by repositioning of loaded Mcm2-7 on chromosomes [183][148]. Sequence-independent (but not necessarily random) initiator binding to DNA additionally allows for flexibility in specifying helicase loading sites and, together with transcriptional interference and the variability in activation efficiencies of licensed origins, likely determines origin location and contributes to the co-regulation of DNA replication and transcriptional programs during development and cell fate transitions. Computational modeling of initiation events in S. pombe, as well as the identification of celltype specific and developmentally-regulated origins in metazoans, are in agreement with this notion [136][144][184][185][186][187][188][148]. However, a large degree of flexibility in origin choice also exists among different cells within a single population [139][145][185], and the 
molecular mechanisms that lead to the heterogeneity in origin usage remain ill-defined. Mapping origins in single cells in metazoan systems and correlating these initiation events with single-cell gene expression and chromatin status will be important to elucidate whether origin choice is purely stochastic or controlled in a defined manner.

\section{Concluding remarks}

Although DNA replication is essential for genetic inheritance, defined, site-specific replication origins are technically not a requirement for genome duplication as long as all chromosomes are copied in their entirety to maintain gene copy numbers. Certain bacteriophages and viruses, for example, can initiate DNA replication by homologous recombination independent of dedicated origins [189]. Likewise, the archaeon Haloferax volcanii uses recombinationdependent initiation to duplicate its genome when its endogenous origins are deleted [78]. Similar non-canonical initiation events through break-induced or transcription-initiated replication have been reported in E. coli and S. cerevisiae [190][191][192][193][194]. Nonetheless, despite the ability of cells to sustain viability under these exceptional circumstances, origin-dependent initiation is a common strategy universally adopted across different domains of life. The controlled assembly of the replication machinery at origins likely confers longterm advantage to cells by allowing tight cell cycle regulation and by maintaining a specific replication dynamics. The divergent origin specification modes between prokaryotes and budding yeast on the one hand and metazoans on the other hand appear to reflect distinct needs to coordinate the spatiotemporal replication program with gene expression and cell differentiation programs to ensure not only genetic but also epigenetic inheritance and to preserve cell identity. Deciphering the underlying molecular mechanisms that modulate origin location, usage, and timing to define the replication program in metazoan systems represents an important major challenge in the field and will be essential to understand how dysregulation of these events are linked to human diseases. In addition, detailed studies of replication initiation have focused on a limited number of model systems. The extensively studied fungi and metazoa are both members of the opisthokont supergroup and exemplify only a small fraction of the evolutionary landscape in the eukaryotic domain [195]. Comparably few efforts have been directed at other eukaryotic model systems, such as kinetoplastids or tetrahymena [196][197][198][199][200] [201][202]. Surprisingly, these studies have revealed interesting differences both in origin properties and in initiator composition compared to yeast and metazoans. Further exploration of replication initiation mechanisms across different branches of the eukaryotic domain will likely yield unexpected insight into the diversity and evolution of this fundamental biological process.

\section{Supporting information}

\section{S1 Text. Version history of the text file.}

(XML)

S2 Text. Peer reviews and response to reviews.

(XML)

\section{References}

1. Mendel $G$ (1865) Versuche ueber Pflanzenhybriden Verhandlungen des naturforschenden Vereines in Bruenn, Bd IV Abhandlungen:3-47

2. Avery OT, Macleod CM \& McCarty M (1944) Studies on the chemical nature of the substance inducing transformation of pneumococcal types: induction of transformation by a desoxyribonucleic acid 
fraction isolated from pneumococcus type iii J. Exp. Med. 79:137-58 [https://doi.org/10.1084/jem.79. 2.137 PMID: 19871359]

3. Watson JD \& Crick FH (1953) The structure of DNA Cold Spring Harb. Symp. Quant. Biol. 18:123-31 [https://doi.org/10.1101/sqb.1953.018.01.020 PMID: 13168976]

4. Meselson M \& Stahl FW (1958) The replication of DNA in Escherichia coli Proc. Natl. Acad. Sci. U.S. A. 44:671-82 [https://doi.org/10.1073/pnas.44.7.671 PMID: 16590258]

5. Meselson M \& Stahl FW (1958) The replication of DNA Cold Spring Harb. Symp. Quant. Biol. 23:9-12 [https://doi.org/10.1101/sqb.1958.023.01.004 PMID: 13635537]

6. IR Lehman, MJ Bessman, ES Simms \& Kornberg A (1958) Enzymatic synthesis of deoxyribonucleic acid. I. Preparation of substrates and partial purification of an enzyme from Escherichia coli J. Biol. Chem. 233:163-70 [PMID: 13563462]

7. O'Donnell M, Langston L \& Stillman B (2013) Principles and concepts of DNA replication in bacteria, archaea, and eukarya Cold Spring Harb Perspect Biol 5:a010108 [https://doi.org/10.1101/ cshperspect.a010108 PMID: 23818497]

8. Barlow JH \& Nussenzweig A (2014) Replication initiation and genome instability: a crossroads for DNA and RNA synthesis Cell. Mol. Life Sci. 71:4545-59 [https://doi.org/10.1007/s00018-014-1721-1 PMID: 25238783]

9. Abbas T, Keaton MA \& Dutta A (2013) Genomic instability in cancer Cold Spring Harb Perspect Biol 5: a012914 [https://doi.org/10.1101/cshperspect.a012914 PMID: 23335075]

10. Siddiqui K, On KF \& Diffley JF (2013) Regulating DNA replication in eukarya Cold Spring Harb Perspect Biol 5:a012930 [https://doi.org/10.1101/cshperspect.a012930 PMID: 23838438]

11. Sclafani RA \& Holzen TM (2007) Cell cycle regulation of DNA replication Annu. Rev. Genet. 41:23780 [https://doi.org/10.1146/annurev.genet.41.110306.130308 PMID: 17630848]

12. García-Muse T \& Aguilera A (2016) Transcription-replication conflicts: how they occur and how they are resolved Nat. Rev. Mol. Cell Biol. 17:553-63 [https://doi.org/10.1038/nrm.2016.88 PMID: 27435505]

13. Leonard AC \& Méchali M (2013) DNA replication origins Cold Spring Harb Perspect Biol 5:a010116 [https://doi.org/10.1101/cshperspect.a010116 PMID: 23838439]

14. Creager RL, Li Y \& MacAlpine DM (2015) SnapShot: Origins of DNA replication Cell 161:418-418.e1 [https://doi.org/10.1016/j.cell.2015.03.043 PMID: 25860614]

15. Knott SR, Viggiani CJ \& Aparicio OM (2009) To promote and protect: coordinating DNA replication and transcription for genome stability Epigenetics 4:362-5 [https://doi.org/10.4161/epi.4.6.9712 PMID: 19736523]

16. Deshpande AM \& Newlon CS (1996) DNA replication fork pause sites dependent on transcription Science 272:1030-3 [https://doi.org/10.1126/science.272.5264.1030 PMID: 8638128]

17. Sankar TS, Wastuwidyaningtyas BD, Dong Y, Lewis SA \& Wang JD (2016) The nature of mutations induced by replication-transcription collisions Nature 535:178-81 [https://doi.org/10.1038/ nature18316 PMID: 27362223]

18. Liu B \& Alberts BM (1995) Head-on collision between a DNA replication apparatus and RNA polymerase transcription complex Science 267:1131-7 [https://doi.org/10.1126/science.7855590 PMID: 7855590]

19. Azvolinsky A, Giresi PG, Lieb JD \& Zakian VA (2009) Highly transcribed RNA polymerase II genes are impediments to replication fork progression in Saccharomyces cerevisiae Mol. Cell 34:722-34 [https://doi.org/10.1016/j.molcel.2009.05.022 PMID: 19560424]

20. Jacob F, Brenner S \& Cuzin F (1963) On the regulation of DNA replication in bacteria Cold Spring Harbor Symp Quant Biol 28:329-48

21. Novick RP (1987) Plasmid incompatibility Microbiol. Rev. 51:381-95 [PMID: 3325793]

22. Skarstad K \& Katayama T (2013) Regulating DNA replication in bacteria Cold Spring Harb Perspect Biol 5:a012922 [https://doi.org/10.1101/cshperspect.a012922 PMID: 23471435]

23. Marks AB, Fu H \& Aladjem MI (2017) Regulation of Replication Origins Adv. Exp. Med. Biol. 1042:4359 [https://doi.org/10.1007/978-981-10-6955-0_2 PMID: 29357052]

24. Parker MW, Botchan MR \& Berger JM (2017) Mechanisms and regulation of DNA replication initiation in eukaryotes Crit. Rev. Biochem. Mol. Biol. 52:107-44 [https://doi.org/10.1080/10409238.2016. 1274717 PMID: 28094588]

25. Gilbert DM (2004) In search of the holy replicator Nat. Rev. Mol. Cell Biol. 5:848-55 [https://doi.org/ 10.1038/nrm1495 PMID: 15459665]

26. Aladjem MI \& Fanning E (2004) The replicon revisited: an old model learns new tricks in metazoan chromosomes EMBO Rep. 5:686-91 [https://doi.org/10.1038/sj.embor.7400185 PMID: 15229645] 
27. Remus D, Beall EL \& Botchan MR (2004) DNA topology, not DNA sequence, is a critical determinant for Drosophila ORC-DNA binding EMBO J. 23:897-907 [https://doi.org/10.1038/sj.emboj.7600077 PMID: 14765124]

28. Vashee S, Cvetic C, Lu W, Simancek P, Kelly TJ \& Walter JC (2003) Sequence-independent DNA binding and replication initiation by the human origin recognition complex Genes Dev. 17:1894-908 [https://doi.org/10.1101/gad.1084203 PMID: 12897055]

29. Shen Z, Sathyan KM, Geng Y, Zheng R, Chakraborty A, Freeman B, Wang F, Prasanth KV \& Prasanth SG (2010) A WD-repeat protein stabilizes ORC binding to chromatin Mol. Cell 40:99-111 [https://doi. org/10.1016/j.molcel.2010.09.021 PMID: 20932478]

30. Dorn ES \& Cook JG (2011) Nucleosomes in the neighborhood: new roles for chromatin modifications in replication origin control Epigenetics 6:552-9 [https://doi.org/10.4161/epi.6.5.15082 PMID: 21364325]

31. Aladjem MI \& Redon CE (2017) Order from clutter: selective interactions at mammalian replication origins Nat. Rev. Genet. 18:101-16 [https://doi.org/10.1038/nrg.2016.141 PMID: 27867195]

32. Fragkos M, Ganier O, Coulombe $P$ \& Méchali M (2015) DNA replication origin activation in space and time Nat. Rev. Mol. Cell Biol. 16:360-74 [https://doi.org/10.1038/nrm4002 PMID: 25999062]

33. Prioleau MN \& MacAlpine DM (2016) DNA replication origins-where do we begin? Genes Dev. 30:1683-97 [https://doi.org/10.1101/gad.285114.116 PMID: 27542827]

34. Cayrou C, Coulombe P, Puy A, Rialle S, Kaplan N, Segal E \& Méchali M (2012) New insights into replication origin characteristics in metazoans Cell Cycle 11:658-67 [https://doi.org/10.4161/cc.11.4. 19097 PMID: 22373526]

35. Lombraña R, Almeida R, Álvarez A \& Gómez M (2015) R-loops and initiation of DNA replication in human cells: a missing link? Front Genet 6:158 [https://doi.org/10.3389/fgene.2015.00158 PMID: 25972891]

36. Jang SM, Zhang Y, Utani K, Fu H, Redon CE, Marks AB, Smith OK, Redmond CJ, Baris AM, Tulchinsky DA \& Aladjem MI (2018) The replication initiation determinant protein (RepID) modulates replication by recruiting CUL4 to chromatin Nat Commun 9:2782 [https://doi.org/10.1038/s41467-01805177-6 PMID: 30018425]

37. Zakian VA \& Scott JF (1982) Construction, replication, and chromatin structure of TRP1 RI circle, a multiple-copy synthetic plasmid derived from Saccharomyces cerevisiae chromosomal DNA Mol. Cell. Biol. 2:221-32 [https://doi.org/10.1128/mcb.2.3.221 PMID: 6287231]

38. Rhodes N, Company M \& Errede B (1990) A yeast-Escherichia coli shuttle vector containing the M13 origin of replication Plasmid 23:159-62 [PMID: 2194231]

39. Paululat A \& Heinisch JJ (2012) New yeast/E. coli/Drosophila triple shuttle vectors for efficient generation of Drosophila P element transformation constructs Gene 511:300-5 [https://doi.org/10.1016/j. gene.2012.09.058 PMID: 23026211]

40. Ryan VT, Grimwade JE, Camara JE, Crooke E \& Leonard AC (2004) Escherichia coli prereplication complex assembly is regulated by dynamic interplay among Fis, IHF and DnaA Mol. Microbiol. 51:1347-59 [https://doi.org/10.1046/j.1365-2958.2003.03906.x PMID: 14982629]

41. Mackiewicz P, Zakrzewska-Czerwinska J, Zawilak A, Dudek MR \& Cebrat S (2004) Where does bacterial replication start? Rules for predicting the oriC region Nucleic Acids Res. 32:3781-91 [https://doi. org/10.1093/nar/gkh699 PMID: 15258248]

42. Luo H \& Gao F (2019) DoriC 10.0: an updated database of replication origins in prokaryotic genomes including chromosomes and plasmids Nucleic Acids Res. 47:D74-D77 [https://doi.org/10.1093/nar/ gky1014 PMID: 30364951]

43. Fuller RS, Funnell BE \& Kornberg A (1984) The dnaA protein complex with the E. coli chromosomal replication origin (oriC) and other DNA sites Cell 38:889-900 [https://doi.org/10.1016/0092-8674(84) 90284-8 PMID: 6091903]

44. Fuller RS \& Kornberg A (1983) Purified dnaA protein in initiation of replication at the Escherichia coli chromosomal origin of replication Proc. Natl. Acad. Sci. U.S.A. 80:5817-21 [https://doi.org/10.1073/ pnas.80.19.5817 PMID: 6310593]

45. Jakimowicz D, Majka J, Messer W, Speck C, Fernandez M, Martin MC, Sanchez J, Schauwecker F, Keller U, Schrempf H \& Zakrzewska-Czerwińska J (1998) Structural elements of the Streptomyces oriC region and their interactions with the DnaA protein Microbiology 144:1281-90 [https://doi.org/10. 1099/00221287-144-5-1281 PMID: 9611803]

46. Tsodikov OV \& Biswas $T$ (2011) Structural and thermodynamic signatures of DNA recognition by Mycobacterium tuberculosis DnaA J. Mol. Biol. 410:461-76 [https://doi.org/10.1016/j.jmb.2011.05. 007 PMID: 21620858] 
47. Costa A, Hood IV \& Berger JM (2013) Mechanisms for initiating cellular DNA replication Annu. Rev. Biochem. 82:25-54 [https://doi.org/10.1146/annurev-biochem-052610-094414 PMID: 23746253]

48. Wolański M, Donczew R, Zawilak-Pawlik A \& Zakrzewska-Czerwińska J (2014) oriC-encoded instructions for the initiation of bacterial chromosome replication Front Microbiol 5:735 [https://doi.org/10. 3389/fmicb.2014.00735 PMID: 25610430]

49. Messer W, Blaesing F, Majka J, Nardmann J, Schaper S, Schmidt A, Seitz H, Speck C, Tüngler D, Wegrzyn G, Weigel C, Welzeck M \& Zakrzewska-Czerwinska J (1999) Functional domains of DnaA proteins Biochimie 81:819-25 [https://doi.org/10.1016/s0300-9084(99)00215-1 PMID: 10572294]

50. Sutton MD \& Kaguni JM (1997) The Escherichia coli dnaA gene: four functional domains J. Mol. Biol. 274:546-61 [https://doi.org/10.1006/jmbi.1997.1425 PMID: 9417934]

51. Speck C \& Messer W (2001) Mechanism of origin unwinding: sequential binding of DnaA to doubleand single-stranded DNA EMBO J. 20:1469-76 [https://doi.org/10.1093/emboj/20.6.1469 PMID: 11250912]

52. Fujikawa N, Kurumizaka H, Nureki O, Terada T, Shirouzu M, Katayama T \& Yokoyama S (2003) Structural basis of replication origin recognition by the DnaA protein Nucleic Acids Res. 31:2077-86 [https://doi.org/10.1093/nar/gkg309 PMID: 12682358]

53. Duderstadt KE, Chuang K \& Berger JM (2011) DNA stretching by bacterial initiators promotes replication origin opening Nature 478:209-13 [https://doi.org/10.1038/nature10455 PMID: 21964332]

54. Erzberger JP, Pirruccello MM \& Berger JM (2002) The structure of bacterial DnaA: implications for general mechanisms underlying DNA replication initiation EMBO J. 21:4763-73 [https://doi.org/10. 1093/emboj/cdf496 PMID: 12234917]

55. Iyer LM, Leipe DD, Koonin EV \& Aravind L (2004) Evolutionary history and higher order classification of AAA+ ATPases J. Struct. Biol. 146:11-31 [https://doi.org/10.1016/j.jsb.2003.10.010 PMID: 15037234]

56. Sutton MD \& Kaguni JM (1997) Threonine 435 of Escherichia coli DnaA protein confers sequencespecific DNA binding activity J. Biol. Chem. 272:23017-24 [https://doi.org/10.1074/jbc.272.37.23017 PMID: 9287298]

57. Bramhill D \& Kornberg A (1988) A model for initiation at origins of DNA replication Cell 54:915-8 [https://doi.org/10.1016/0092-8674(88)90102-x PMID: 2843291]

58. Rozgaja TA, Grimwade JE, Iqbal M, Czerwonka C, Vora M \& Leonard AC (2011) Two oppositely oriented arrays of low-affinity recognition sites in oriC guide progressive binding of DnaA during Escherichia coli pre-RC assembly Mol. Microbiol. 82:475-88 [https://doi.org/10.1111/j.1365-2958.2011. 07827.x PMID: 21895796]

59. Zawilak-Pawlik A, Kois A, Majka J, Jakimowicz D, Smulczyk-Krawczyszyn A, Messer W \& Zakrzewska-Czerwińska J (2005) Architecture of bacterial replication initiation complexes: orisomes from four unrelated bacteria Biochem. J. 389:471-81 [https://doi.org/10.1042/BJ20050143 PMID: 15790315]

60. Grimwade JE, Rozgaja TA, Gupta R, Dyson K, Rao P \& Leonard AC (2018) Origin recognition is the predominant role for DnaA-ATP in initiation of chromosome replication Nucleic Acids Res. 46:6140 51 [https://doi.org/10.1093/nar/gky457 PMID: 29800247]

61. Sakiyama $Y$, Kasho K, Noguchi $Y$, Kawakami H \& Katayama $T$ (2017) Regulatory dynamics in the ternary DnaA complex for initiation of chromosomal replication in Escherichia coli Nucleic Acids Res. 45:12354-73 [https://doi.org/10.1093/nar/gkx914 PMID: 29040689]

62. Matsui M, Oka A, Takanami M, Yasuda S \& Hirota Y (1985) Sites of dnaA protein-binding in the replication origin of the Escherichia coli K-12 chromosome J. Mol. Biol. 184:529-33 [https://doi.org/10. 1016/0022-2836(85)90299-2 PMID: 2995681]

63. Margulies C \& Kaguni JM (1996) Ordered and sequential binding of DnaA protein to oriC, the chromosomal origin of Escherichia coli J. Biol. Chem. 271:17035-40 [https://doi.org/10.1074/jbc.271.29. 17035 PMID: 8663334]

64. Schaper S \& Messer W (1995) Interaction of the initiator protein DnaA of Escherichia coli with its DNA target J. Biol. Chem. 270:17622-6 [https://doi.org/10.1074/jbc.270.29.17622 PMID: 7615570]

65. Weigel C, Schmidt A, Rückert B, Lurz R \& Messer W (1997) DnaA protein binding to individual DnaA boxes in the Escherichia coli replication origin, oriC EMBO J. 16:6574-83 [https://doi.org/10.1093/ emboj/16.21.6574 PMID: 9351837]

66. Samitt CE, Hansen FG, Miller JF \& Schaechter M (1989) In vivo studies of DnaA binding to the origin of replication of Escherichia coli EMBO J. 8:989-93 [PMID: 2542031]

67. McGarry KC, Ryan VT, Grimwade JE \& Leonard AC (2004) Two discriminatory binding sites in the Escherichia coli replication origin are required for DNA strand opening by initiator DnaA-ATP Proc. Natl. Acad. Sci. U.S.A. 101:2811-6 [https://doi.org/10.1073/pnas.0400340101 PMID: 14978287] 
68. Kawakami H, Keyamura K \& Katayama T (2005) Formation of an ATP-DnaA-specific initiation complex requires DnaA Arginine 285, a conserved motif in the AAA+ protein family J. Biol. Chem. 280:27420-30 [https://doi.org/10.1074/jbc.M502764200 PMID: 15901724]

69. Speck C, Weigel C \& Messer W (1999) ATP- and ADP-dnaA protein, a molecular switch in gene regulation EMBO J. 18:6169-76 [https://doi.org/10.1093/emboj/18.21.6169 PMID: 10545126]

70. Miller DT, Grimwade JE, Betteridge T, Rozgaja T, Torgue JJ \& Leonard AC (2009) Bacterial origin recognition complexes direct assembly of higher-order DnaA oligomeric structures Proc. Natl. Acad. Sci. U.S.A. 106:18479-84 [https://doi.org/10.1073/pnas.0909472106 PMID: 19833870]

71. Erzberger JP, Mott ML \& Berger JM (2006) Structural basis for ATP-dependent DnaA assembly and replication-origin remodeling Nat. Struct. Mol. Biol. 13:676-83 [https://doi.org/10.1038/nsmb1115 PMID: 16829961]

72. Zorman S, Seitz H, Sclavi B \& Strick TR (2012) Topological characterization of the DnaA-oriC complex using single-molecule nanomanipuation Nucleic Acids Res. 40:7375-83 [https://doi.org/10.1093/nar/ gks371 PMID: 22581769]

73. Richardson TT, Harran O \& Murray H (2016) The bacterial DnaA-trio replication origin element specifies single-stranded DNA initiator binding Nature 534:412-6 [https://doi.org/10.1038/nature17962 PMID: 27281207]

74. Duderstadt KE, Mott ML, Crisona NJ, Chuang K, Yang H \& Berger JM (2010) Origin remodeling and opening in bacteria rely on distinct assembly states of the DnaA initiator J. Biol. Chem. 285:28229-39 [https://doi.org/10.1074/jbc.M110.147975 PMID: 20595381]

75. Ozaki S \& Katayama T (2012) Highly organized DnaA-oriC complexes recruit the single-stranded DNA for replication initiation Nucleic Acids Res. 40:1648-65 [https://doi.org/10.1093/nar/gkr832 PMID: 22053082]

76. Myllykallio H, Lopez $P$, López-García $\mathrm{P}$, Heilig R, Saurin $\mathrm{W}$, Zivanovic $\mathrm{Y}$, Philippe H \& Forterre $\mathrm{P}$ (2000) Bacterial mode of replication with eukaryotic-like machinery in a hyperthermophilic archaeon Science 288:2212-5 [https://doi.org/10.1126/science.288.5474.2212 PMID: 10864870]

77. Norais C, Hawkins M, Hartman AL, Eisen JA, Myllykallio H \& Allers T (2007) Genetic and physical mapping of DNA replication origins in Haloferax volcanii PLoS Genet. 3:e77 [https://doi.org/10.1371/ journal.pgen.0030077 PMID: 17511521]

78. Hawkins M, Malla S, Blythe MJ, Nieduszynski CA \& Allers T (2013) Accelerated growth in the absence of DNA replication origins Nature 503 544-7 [https://doi.org/10.1038/nature12650 PMID: 24185008]

79. Wu Z, Liu J, Yang H, Liu H \& Xiang H (2014) Multiple replication origins with diverse control mechanisms in Haloarcula hispanica Nucleic Acids Res. 42:2282-94 [https://doi.org/10.1093/nar/gkt1214 PMID: 24271389]

80. Pelve EA, Martens-Habbena W, Stahl DA \& Bernander R (2013) Mapping of active replication origins in vivo in thaum- and euryarchaeal replicons Mol. Microbiol. 90:538-50 [https://doi.org/10.1111/mmi. 12382 PMID: 23991938]

81. Pelve EA, Lindås AC, Knöppel A, Mira A \& Bernander R (2012) Four chromosome replication origins in the archaeon Pyrobaculum calidifontis Mol. Microbiol. 85:986-95 [https://doi.org/10.1111/j.13652958.2012.08155.x PMID: 22812406]

82. Robinson NP, Dionne I, Lundgren M, Marsh VL, Bernander R \& Bell SD (2004) Identification of two origins of replication in the single chromosome of the archaeon Sulfolobus solfataricus Cell 116:25-38 [https://doi.org/10.1016/s0092-8674(03)01034-1 PMID: 14718164]

83. Lundgren M, Andersson A, Chen L, Nilsson P \& Bernander R (2004) Three replication origins in Sulfolobus species: synchronous initiation of chromosome replication and asynchronous termination Proc. Natl. Acad. Sci. U.S.A. 101:7046-51 [https://doi.org/10.1073/pnas.0400656101 PMID: 15107501]

84. Bell SD (2017) Initiation of DNA Replication in the Archaea Adv. Exp. Med. Biol. 1042:99-115 [https:// doi.org/10.1007/978-981-10-6955-0_5 PMID: 29357055]

85. Ausiannikava D \& Allers T (2017) Diversity of DNA Replication in the Archaea Genes (Basel) 8:E56 [https://doi.org/10.3390/genes8020056 PMID: 28146124]

86. Wu Z, Liu J, Yang H \& Xiang H (2014) DNA replication origins in archaea Front Microbiol 5:179 [https://doi.org/10.3389/fmicb.2014.00179 PMID: 24808892]

87. Matsunaga F, Forterre $\mathrm{P}$, Ishino $\mathrm{Y} \&$ Myllykallio $\mathrm{H}$ (2001) In vivo interactions of archaeal Cdc6/Orc1 and minichromosome maintenance proteins with the replication origin Proc. Natl. Acad. Sci. U.S.A. 98:11152-7 [https://doi.org/10.1073/pnas.191387498 PMID: 11562464]

88. Wu Z, Liu H, Liu J, Liu X \& Xiang H (2012) Diversity and evolution of multiple orc/cdc6-adjacent replication origins in haloarchaea BMC Genomics 13:478 [https://doi.org/10.1186/1471-2164-13-478 PMID: 22978470] 
89. Bell SD (2012) Archaeal orc1/cdc6 proteins Subcell. Biochem. 62:59-69 [https://doi.org/10.1007/97894-007-4572-8_4 PMID: 22918580]

90. Samson RY, Xu Y, Gadelha C, Stone TA, Faqiri JN, Li D, Qin N, Pu F, Liang YX, She Q \& Bell SD (2013) Specificity and function of archaeal DNA replication initiator proteins Cell Rep 3:485-96 [https://doi.org/10.1016/j.celrep.2013.01.002 PMID: 23375370]

91. Grainge I, Gaudier M, Schuwirth BS, Westcott SL, Sandall J, Atanassova N \& Wigley DB (2006) Biochemical analysis of a DNA replication origin in the archaeon Aeropyrum pernix J. Mol. Biol. 363:35569 [https://doi.org/10.1016/j.jmb.2006.07.076 PMID: 16978641]

92. Robinson NP \& Bell SD (2007) Extrachromosomal element capture and the evolution of multiple replication origins in archaeal chromosomes Proc. Natl. Acad. Sci. U.S.A. 104:5806-11 [https://doi.org/ 10.1073/pnas.0700206104 PMID: 17392430]

93. Robinson NP, Blood KA, McCallum SA, Edwards PA \& Bell SD (2007) Sister chromatid junctions in the hyperthermophilic archaeon Sulfolobus solfataricus EMBO J. 26:816-24 [https://doi.org/10.1038/ sj.emboj.7601529 PMID: 17255945]

94. Dueber EL, Corn JE, Bell SD \& Berger JM (2007) Replication origin recognition and deformation by a heterodimeric archaeal Orc1 complex Science 317:1210-3 [https://doi.org/10.1126/science.1143690 PMID: 17761879]

95. Gaudier M, Schuwirth BS, Westcott SL \& Wigley DB (2007) Structural basis of DNA replication origin recognition by an ORC protein Science 317:1213-6 [https://doi.org/10.1126/science.1143664 PMID: 17761880]

96. Capaldi SA \& Berger JM (2004) Biochemical characterization of Cdc6/Orc1 binding to the replication origin of the euryarchaeon Methanothermobacter thermoautotrophicus Nucleic Acids Res. 32:482132 [https://doi.org/10.1093/nar/gkh819 PMID: 15358831]

97. Liu J, Smith CL, DeRyckere D, DeAngelis K, Martin GS \& Berger JM (2000) Structure and function of Cdc6/Cdc18: implications for origin recognition and checkpoint control Mol. Cell 6:637-48 [PMID: 11030343]

98. Singleton MR, Morales R, Grainge I, Cook N, Isupov MN \& Wigley DB (2004) Conformational changes induced by nucleotide binding in Cdc6/ORC from Aeropyrum pernix J. Mol. Biol. 343:547-57 [https:// doi.org/10.1016/j.jmb.2004.08.044 PMID: 15465044]

99. Matsunaga F, Norais C, Forterre P \& Myllykallio H (2003) Identification of short 'eukaryotic' Okazaki fragments synthesized from a prokaryotic replication origin EMBO Rep. 4:154-8 [https://doi.org/10. 1038/sj.embor.embor732 PMID: 12612604]

100. Berquist BR \& DasSarma S (2003) An archaeal chromosomal autonomously replicating sequence element from an extreme halophile, Halobacterium sp. strain NRC-1 J. Bacteriol. 185:5959-66 [https:// doi.org/10.1128/JB.185.20.5959-5966.2003 PMID: 14526006]

101. Kasiviswanathan R, Shin JH \& Kelman Z (2005) Interactions between the archaeal Cdc6 and MCM proteins modulate their biochemical properties Nucleic Acids Res. 33:4940-50 [https://doi.org/10. 1093/nar/gki807 PMID: 16150924]

102. Samson RY, Abeyrathne PD \& Bell SD (2016) Mechanism of Archaeal MCM Helicase Recruitment to DNA Replication Origins Mol. Cell 61:287-96 [https://doi.org/10.1016/j.molcel.2015.12.005 PMID: 26725007]

103. Dueber EC, Costa A, Corn JE, Bell SD \& Berger JM (2011) Molecular determinants of origin discrimination by Orc1 initiators in archaea Nucleic Acids Res. 39:3621-31 [https://doi.org/10.1093/nar/ gkq1308 PMID: 21227921]

104. Matsunaga F, Takemura K, Akita M, Adachi A, Yamagami T \& Ishino Y (2010) Localized melting of duplex DNA by Cdc6/Orc1 at the DNA replication origin in the hyperthermophilic archaeon Pyrococcus furiosus Extremophiles 14:21-31 [https://doi.org/10.1007/s00792-009-0284-9 PMID: 19787415]

105. Onishi M, Liou GG, Buchberger JR, Walz T \& Moazed D (2007) Role of the conserved Sir3-BAH domain in nucleosome binding and silent chromatin assembly Mol. Cell 28:1015-28 [https://doi.org/ 10.1016/j.molcel.2007.12.004 PMID: 18158899]

106. Kuo AJ, Song J, Cheung P, Ishibe-Murakami S, Yamazoe S, Chen JK, Patel DJ \& Gozani O (2012) The BAH domain of ORC1 links H4K20me2 to DNA replication licensing and Meier-Gorlin syndrome Nature 484:115-9 [https://doi.org/10.1038/nature10956 PMID: 22398447]

107. Bleichert F, Botchan MR \& Berger JM (2017) Mechanisms for initiating cellular DNA replication Science 355:aah6317 [https://doi.org/10.1126/science.aah6317 PMID: 28209641]

108. Gambus A, Khoudoli GA, Jones RC \& Blow JJ (2011) MCM2-7 form double hexamers at licensed origins in Xenopus egg extract J. Biol. Chem. 286:11855-64 [https://doi.org/10.1074/jbc.M110.199521 PMID: 21282109] 
109. Remus D, Beuron F, Tolun G, Griffith JD, Morris EP \& Diffley JF (2009) Concerted loading of Mcm2-7 double hexamers around DNA during DNA replication origin licensing Cell 139:719-30 [https://doi. org/10.1016/j.cell.2009.10.015 PMID: 19896182]

110. Evrin C, Clarke P, Zech J, Lurz R, Sun J, Uhle S, Li H, Stillman B \& Speck C (2009) A double-hexameric MCM2-7 complex is loaded onto origin DNA during licensing of eukaryotic DNA replication Proc. Natl. Acad. Sci. U.S.A. 106:20240-5 [https://doi.org/10.1073/pnas.0911500106 PMID: 19910535]

111. Ge XQ, Jackson DA \& Blow JJ (2007) Dormant origins licensed by excess Mcm2-7 are required for human cells to survive replicative stress Genes Dev. 21:3331-41 [https://doi.org/10.1101/gad. 457807 PMID: 18079179]

112. Ibarra A, Schwob E \& Méndez J (2008) Excess MCM proteins protect human cells from replicative stress by licensing backup origins of replication Proc. Natl. Acad. Sci. U.S.A. 105:8956-61 [https:// doi.org/10.1073/pnas.0803978105 PMID: 18579778]

113. Stinchcomb DT, Struhl K \& Davis RW (1979) Isolation and characterisation of a yeast chromosomal replicator Nature 282:39-43 [https://doi.org/10.1038/282039a0 PMID: 388229]

114. Huberman JA, Spotila LD, Nawotka KA, el-Assouli SM \& Davis LR (1987) The in vivo replication origin of the yeast 2 microns plasmid Cell 51:473-81 [https://doi.org/10.1016/0092-8674(87)90643-x PMID: 3311385]

115. Brewer BJ \& Fangman WL (1987) The localization of replication origins on ARS plasmids in S. cerevisiae Cell 51:463-71 [https://doi.org/10.1016/0092-8674(87)90642-8 PMID: 2822257]

116. Marahrens $Y$ \& Stillman $B$ (1992) A yeast chromosomal origin of DNA replication defined by multiple functional elements Science 255:817-23 [https://doi.org/10.1126/science.1536007 PMID: 1536007]

117. Rao H, Marahrens $Y$ \& Stillman $B$ (1994) Functional conservation of multiple elements in yeast chromosomal replicators Mol. Cell. Biol. 14:7643-51 [https://doi.org/10.1128/mcb.14.11.7643 PMID: 7935478]

118. Broach JR, Li YY, Feldman J, Jayaram M, Abraham J, Nasmyth KA \& Hicks JB (1983) Localization and sequence analysis of yeast origins of DNA replication Cold Spring Harb. Symp. Quant. Biol. $47 \mathrm{Pt}$ 2:1165-73 [https://doi.org/10.1101/sqb.1983.047.01.132 PMID: 6345070]

119. Celniker SE, Sweder K, Srienc F, Bailey JE \& Campbell JL (1984) Deletion mutations affecting autonomously replicating sequence ARS1 of Saccharomyces cerevisiae Mol. Cell. Biol. 4:2455-66 [https:// doi.org/10.1128/mcb.4.11.2455 PMID: 6392851]

120. Rao H \& Stillman $B$ (1995) The origin recognition complex interacts with a bipartite DNA binding site within yeast replicators Proc. Natl. Acad. Sci. U.S.A. 92:2224-8 [https://doi.org/10.1073/pnas.92.6. 2224 PMID: 7892251]

121. Rowley A, Cocker JH, Harwood J \& Diffley JF (1995) Initiation complex assembly at budding yeast replication origins begins with the recognition of a bipartite sequence by limiting amounts of the initiator, ORC EMBO J. 14:2631-41 [PMID: 7781615]

122. Bell SP \& Stillman B (1992) ATP-dependent recognition of eukaryotic origins of DNA replication by a multiprotein complex Nature 357:128-34 [https://doi.org/10.1038/357128a0 PMID: 1579162]

123. Li N, Lam WH, Zhai Y, Cheng J, Cheng E, Zhao Y, Gao N \& Tye BK (2018) Structure of the origin recognition complex bound to DNA replication origin Nature 559:217-222 [https://doi.org/10.1038/ s41586-018-0293-x PMID: 29973722]

124. Bleichert F, Botchan MR \& Berger JM (2015) Crystal structure of the eukaryotic origin recognition complex Nature 519:321-6 [https://doi.org/10.1038/nature14239 PMID: 25762138]

125. Sun J, Evrin C, Samel SA, Fernández-Cid A, Riera A, Kawakami H, Stillman B, Speck C \& Li H (2013) Cryo-EM structure of a helicase loading intermediate containing ORC-Cdc6-Cdt1-MCM2-7 bound to DNA Nat. Struct. Mol. Biol. 20:944-51 [https://doi.org/10.1038/nsmb.2629 PMID: 23851460]

126. Kawakami H, Ohashi E, Kanamoto S, Tsurimoto T \& Katayama T (2015) Specific binding of eukaryotic ORC to DNA replication origins depends on highly conserved basic residues Sci Rep 5:14929 [https:// doi.org/10.1038/srep14929 PMID: 26456755]

127. Palzkill TG \& Newlon CS (1988) A yeast replication origin consists of multiple copies of a small conserved sequence Cell 53:441-50 [https://doi.org/10.1016/0092-8674(88)90164-x PMID: 3284655]

128. Wilmes GM \& Bell SP (2002) The B2 element of the Saccharomyces cerevisiae ARS1 origin of replication requires specific sequences to facilitate pre-RC formation Proc. Natl. Acad. Sci. U.S.A. 99:101-6 [https://doi.org/10.1073/pnas.012578499 PMID: 11756674]

129. Coster G \& Diffley JFX (2017) Bidirectional eukaryotic DNA replication is established by quasi-symmetrical helicase loading Science 357:314-8 [https://doi.org/10.1126/science.aan0063 PMID: 28729513]

130. Zou L \& Stillman B (2000) Assembly of a complex containing Cdc45p, replication protein A, and Mcm2p at replication origins controlled by S-phase cyclin-dependent kinases and Cdc7p-Dbf4p kinase Mol. Cell. Biol. 20:3086-96 [https://doi.org/10.1128/mcb.20.9.3086-3096.2000 PMID: 10757793] 
131. Lipford JR \& Bell SP (2001) Nucleosomes positioned by ORC facilitate the initiation of DNA replication Mol. Cell 7:21-30 [PMID: 11172708]

132. Diffley JF \& Cocker JH (1992) Protein-DNA interactions at a yeast replication origin Nature 357:16972 [https://doi.org/10.1038/357169a0 PMID: 1579168]

133. Diffley JF \& Stillman B (1988) Purification of a yeast protein that binds to origins of DNA replication and a transcriptional silencer Proc. Natl. Acad. Sci. U.S.A. 85:2120-4 [https://doi.org/10.1073/pnas.85.7. 2120 PMID: 3281162]

134. Miotto B, Ji Z \& Struhl $\mathrm{K}$ (2016) Selectivity of ORC binding sites and the relation to replication timing, fragile sites, and deletions in cancers Proc. Natl. Acad. Sci. U.S.A. 113:E4810-9 [https://doi.org/10. 1073/pnas.1609060113 PMID: 27436900]

135. MacAlpine HK, Gordân R, Powell SK, Hartemink AJ \& MacAlpine DM (2010) Drosophila ORC localizes to open chromatin and marks sites of cohesin complex loading Genome Res. 20:201-11 [https:// doi.org/10.1101/gr.097873.109 PMID: 19996087]

136. Eaton ML, Prinz JA, MacAlpine HK, Tretyakov G, Kharchenko PV \& MacAlpine DM (2011) Chromatin signatures of the Drosophila replication program Genome Res. 21:164-74 [https://doi.org/10.1101/gr. 116038.110 PMID: 21177973]

137. Dellino GI, Cittaro D, Piccioni R, Luzi L, Banfi S, Segalla S, Cesaroni M, Mendoza-Maldonado R, Giacca M \& Pelicci PG (2013) Genome-wide mapping of human DNA-replication origins: levels of transcription at ORC1 sites regulate origin selection and replication timing Genome Res. 23:1-11 [https:// doi.org/10.1101/gr.142331.112 PMID: 23187890]

138. Cayrou C, Ballester B, Peiffer I, Fenouil R, Coulombe P, Andrau JC, van Helden J \& Méchali M (2015) The chromatin environment shapes DNA replication origin organization and defines origin classes Genome Res. 25:1873-85 [https://doi.org/10.1101/gr.192799.115 PMID: 26560631]

139. Cayrou C, Coulombe P, Vigneron A, Stanojcic S, Ganier O, Peiffer I, Rivals E, Puy A, Laurent-Chabalier S, Desprat R \& Méchali M (2011) Genome-scale analysis of metazoan replication origins reveals their organization in specific but flexible sites defined by conserved features Genome Res. 21:143849 [https://doi.org/10.1101/gr.121830.111 PMID: 21750104]

140. Lubelsky Y, Sasaki T, Kuipers MA, Lucas I, Le Beau MM, Carignon S, Debatisse M, Prinz JA, Dennis JH \& Gilbert DM (2011) Pre-replication complex proteins assemble at regions of low nucleosome occupancy within the Chinese hamster dihydrofolate reductase initiation zone Nucleic Acids Res. 39:3141-55 [https://doi.org/10.1093/nar/gkq1276 PMID: 21148149]

141. Hayashi M, Katou Y, Itoh T, Tazumi A, Tazumi M, Yamada Y, Takahashi T, Nakagawa T, Shirahige K \& Masukata $\mathrm{H}$ (2007) Genome-wide localization of pre-RC sites and identification of replication origins in fission yeast EMBO J. 26:1327-39 [https://doi.org/10.1038/sj.emboj.7601585 PMID: 17304213]

142. Martin MM, Ryan M, Kim R, Zakas AL, Fu H, Lin CM, Reinhold WC, Davis SR, Bilke S, Liu H, Doroshow JH, Reimers MA, Valenzuela MS, Pommier Y, Meltzer PS \& Aladjem MI (2011) Genome-wide depletion of replication initiation events in highly transcribed regions Genome Res. 21:1822-32 [https://doi.org/10.1101/gr.124644.111 PMID: 21813623]

143. Pourkarimi E, Bellush JM \& Whitehouse I (2016) Spatiotemporal coupling and decoupling of gene transcription with DNA replication origins during embryogenesis in C. elegans elife 5:e21728 [https://doi. org/10.7554/eLife.21728 PMID: 28009254]

144. Rodríguez-Martínez M, Pinzón N, Ghommidh C, Beyne E, Seitz H, Cayrou C \& Méchali M (2017) The gastrula transition reorganizes replication-origin selection in Caenorhabditis elegans Nat. Struct. Mol. Biol. 24:290-9 [https://doi.org/10.1038/nsmb.3363 PMID: 28112731]

145. Besnard E, Babled A, Lapasset L, Milhavet O, Parrinello H, Dantec C, Marin JM \& Lemaitre JM (2012) Unraveling cell type-specific and reprogrammable human replication origin signatures associated with G-quadruplex consensus motifs Nat. Struct. Mol. Biol. 19:837-44 [https://doi.org/10.1038/nsmb.2339 PMID: 22751019]

146. Delgado S, Gómez M, Bird A \& Antequera F (1998) Initiation of DNA replication at CpG islands in mammalian chromosomes EMBO J. 17:2426-35 [https://doi.org/10.1093/emboj/17.8.2426 PMID: 9545253]

147. Sequeira-Mendes J, Díaz-Uriarte R, Apedaile A, Huntley D, Brockdorff N \& Gómez M (2009) Transcription initiation activity sets replication origin efficiency in mammalian cells PLoS Genet. 5: e1000446 [https://doi.org/10.1371/journal.pgen.1000446 PMID: 19360092]

148. Kelly T \& Callegari AJ (2019) Dynamics of DNA replication in a eukaryotic cell Proc. Natl. Acad. Sci. U. S.A. 116:4973-82 [https://doi.org/10.1073/pnas.1818680116 PMID: 30718387]

149. Austin RJ, Orr-Weaver TL \& Bell SP (1999) Drosophila ORC specifically binds to ACE3, an origin of DNA replication control element Genes Dev. 13:2639-49 [https://doi.org/10.1101/gad.13.20.2639 PMID: 10541550] 
150. Beall EL, Manak JR, Zhou S, Bell M, Lipsick JS \& Botchan MR (2002) Role for a Drosophila Myb-containing protein complex in site-specific DNA replication Nature 420:833-7 [https://doi.org/10.1038/ nature01228 PMID: 12490953]

151. Beall EL, Bell M, Georlette D \& Botchan MR (2004) Dm-myb mutant lethality in Drosophila is dependent upon mip130: positive and negative regulation of DNA replication Genes Dev. 18:1667-80 [https://doi.org/10.1101/gad.1206604 PMID: 15256498]

152. Lewis PW, Beall EL, Fleischer TC, Georlette D, Link AJ \& Botchan MR (2004) Identification of a Drosophila Myb-E2F2/RBF transcriptional repressor complex Genes Dev. 18:2929-40 [https://doi.org/ 10.1101/gad.1255204 PMID: 15545624]

153. Bosco G, Du W \& Orr-Weaver TL (2001) DNA replication control through interaction of E2F-RB and the origin recognition complex Nat. Cell Biol. 3:289-95 [https://doi.org/10.1038/35060086 PMID: 11231579]

154. Chuang RY \& Kelly TJ (1999) The fission yeast homologue of Orc4p binds to replication origin DNA via multiple AT-hooks Proc. Natl. Acad. Sci. U.S.A. 96:2656-61 [https://doi.org/10.1073/pnas.96.6. 2656 PMID: 10077566]

155. Balasov M, Huijbregts RP \& Chesnokov I (2007) Role of the Orc6 protein in origin recognition complex-dependent DNA binding and replication in Drosophila melanogaster Mol. Cell. Biol. 27:3143-53 [https://doi.org/10.1128/MCB.02382-06 PMID: 17283052]

156. Tardat M, Brustel J, Kirsh O, Lefevbre C, Callanan M, Sardet C \& Julien E (2010) The histone H4 Lys 20 methyltransferase PR-Set7 regulates replication origins in mammalian cells Nat. Cell Biol. 12:1086-93 [https://doi.org/10.1038/ncb2113 PMID: 20953199]

157. Beck DB, Burton A, Oda H, Ziegler-Birling C, Torres-Padilla ME \& Reinberg D (2012) The role of PRSet7 in replication licensing depends on Suv4-20h Genes Dev. 26:2580-9 [https://doi.org/10.1101/ gad.195636.112 PMID: 23152447]

158. Brustel J, Kirstein N, Izard F, Grimaud C, Prorok P, Cayrou C, Schotta G, Abdelsamie AF, Déjardin J, Méchali M, Baldacci G, Sardet C, Cadoret JC, Schepers A \& Julien E (2017) Histone H4K20 tri-methylation at late-firing origins ensures timely heterochromatin replication EMBO J. 36:2726-41 [https://doi. org/10.15252/embj.201796541 PMID: 28778956]

159. Shoaib M, Walter D, Gillespie PJ, Izard F, Fahrenkrog B, Lleres D, Lerdrup M, Johansen JV, Hansen K, Julien E, Blow JJ \& Sørensen CS (2018) Histone H4K20 methylation mediated chromatin compaction threshold ensures genome integrity by limiting DNA replication licensing Nat Commun 9:3704 [https://doi.org/10.1038/s41467-018-06066-8 PMID: 30209253]

160. Noguchi K, Vassilev A, Ghosh S, Yates JL \& DePamphilis ML (2006) The BAH domain facilitates the ability of human Orc1 protein to activate replication origins in vivo EMBO J. 25:5372-82 [https://doi. org/10.1038/sj.emboj.7601396 PMID: 17066079]

161. Shen Z, Chakraborty A, Jain A, Giri S, Ha T, Prasanth KV \& Prasanth SG (2012) Dynamic association of ORCA with prereplicative complex components regulates DNA replication initiation Mol. Cell. Biol. 32:3107-20 [https://doi.org/10.1128/MCB.00362-12 PMID: 22645314]

162. Wang $Y$, Khan A, Marks AB, Smith OK, Giri S, Lin YC, Creager R, MacAlpine DM, Prasanth KV, Aladjem MI \& Prasanth SG (2017) Temporal association of ORCA/LRWD1 to late-firing origins during G1 dictates heterochromatin replication and organization Nucleic Acids Res. 45:2490-502 [https://doi. org/10.1093/nar/gkw1211 PMID: 27924004]

163. Bartke T, Vermeulen M, Xhemalce B, Robson SC, Mann M \& Kouzarides T (2010) Nucleosome-interacting proteins regulated by DNA and histone methylation Cell 143:470-84 [https://doi.org/10.1016/j. cell.2010.10.012 PMID: 21029866]

164. Vermeulen M, Eberl HC, Matarese F, Marks H, Denissov S, Butter F, Lee KK, Olsen JV, Hyman AA, Stunnenberg HG \& Mann M (2010) Quantitative interaction proteomics and genome-wide profiling of epigenetic histone marks and their readers Cell 142:967-80 [https://doi.org/10.1016/j.cell.2010.08. 020 PMID: 20850016]

165. Hein MY, Hubner NC, Poser I, Cox J, Nagaraj N, Toyoda Y, Gak IA, Weisswange I, Mansfeld J, Buchholz F, Hyman AA \& Mann M (2015) A human interactome in three quantitative dimensions organized by stoichiometries and abundances Cell 163:712-23 [https://doi.org/10.1016/j.cell.2015.09.053 PMID: 26496610]

166. Thomae AW, Pich D, Brocher J, Spindler MP, Berens C, Hock R, Hammerschmidt W \& Schepers A (2008) Interaction between HMGA1a and the origin recognition complex creates site-specific replication origins Proc. Natl. Acad. Sci. U.S.A. 105:1692-7 [https://doi.org/10.1073/pnas.0707260105 PMID: 18234858]

167. Zhang Y, Huang L, Fu H, Smith OK, Lin CM, Utani K, Rao M, Reinhold WC, Redon CE, Ryan M, Kim R, You Y, Hanna H, Boisclair Y, Long Q \& Aladjem MI (2016) A replicator-specific binding protein 
essential for site-specific initiation of DNA replication in mammalian cells Nat Commun 7:11748 [https://doi.org/10.1038/ncomms11748 PMID: 27272143]

168. Bleichert F, Leitner A, Aebersold R, Botchan MR \& Berger JM (2018) Conformational control and DNA-binding mechanism of the metazoan origin recognition complex Proc. Natl. Acad. Sci. U.S.A. 115:E5906-15 [https://doi.org/10.1073/pnas.1806315115 PMID: 29899147]

169. Clarey MG, Botchan M \& Nogales E (2008) Single particle EM studies of the Drosophila melanogaster origin recognition complex and evidence for DNA wrapping J. Struct. Biol. 164:241-9 [https://doi.org/ 10.1016/j.jsb.2008.08.006 PMID: 18824234]

170. Lee DG \& Bell SP (1997) Architecture of the yeast origin recognition complex bound to origins of DNA replication Mol. Cell. Biol. 17:7159-68 [https://doi.org/10.1128/mcb.17.12.7159 PMID: 9372948]

171. Riera A, Barbon M, Noguchi Y, Reuter LM, Schneider S \& Speck C (2017) From structure to mechanism-understanding initiation of DNA replication Genes Dev. 31:1073-88 [https://doi.org/10.1101/ gad.298232.117 PMID: 28717046]

172. Tognetti S, Riera A \& Speck C (2015) Switch on the engine: how the eukaryotic replicative helicase MCM2-7 becomes activated Chromosoma 124:13-26 [https://doi.org/10.1007/s00412-014-0489-2 PMID: 25308420]

173. Berbenetz NM, Nislow C \& Brown GW (2010) Diversity of eukaryotic DNA replication origins revealed by genome-wide analysis of chromatin structure PLoS Genet. 6:e1001092 [https://doi.org/10.1371/ journal.pgen.1001092 PMID: 20824081]

174. Eaton ML, Galani K, Kang S, Bell SP \& MacAlpine DM (2010) Conserved nucleosome positioning defines replication origins Genes Dev. 24:748-53 [https://doi.org/10.1101/gad.1913210 PMID: 20351051]

175. Azmi IF, Watanabe S, Maloney MF, Kang S, Belsky JA, MacAlpine DM, Peterson CL \& Bell SP (2017) Nucleosomes influence multiple steps during replication initiation eLife 6:e22512 [https://doi.org/10. 7554/eLife.22512 PMID: 28322723]

176. Miotto B \& Struhl K (2010) HBO1 histone acetylase activity is essential for DNA replication licensing and inhibited by Geminin Mol. Cell 37:57-66 [https://doi.org/10.1016/j.molcel.2009.12.012 PMID: 20129055]

177. Liu J, Zimmer K, Rusch DB, Paranjape N, Podicheti R, Tang H \& Calvi BR (2015) DNA sequence templates adjacent nucleosome and ORC sites at gene amplification origins in Drosophila Nucleic Acids Res. 43:8746-61 [https://doi.org/10.1093/nar/gkv766 PMID: 26227968]

178. Zhao PA, Rivera-Mulia JC \& Gilbert DM (2017) Replication Domains: Genome Compartmentalization into Functional Replication Units Adv. Exp. Med. Biol. 1042:229-57 [https://doi.org/10.1007/978-98110-6955-0_11 PMID: 29357061]

179. Sugimoto N \& Fujita M (2017) Molecular Mechanism for Chromatin Regulation During MCM Loading in Mammalian Cells Adv. Exp. Med. Biol. 1042:61-78 [https://doi.org/10.1007/978-981-10-6955-0_3 PMID: 29357053]

180. MacAlpine DM \& Almouzni G (2013) Chromatin and DNA replication Cold Spring Harb Perspect Biol 5:a010207 [https://doi.org/10.1101/cshperspect.a010207 PMID: 23751185]

181. Sima J, Chakraborty A, Dileep V, Michalski M, Klein KN, Holcomb NP, Turner JL, Paulsen MT, RiveraMulia JC, Trevilla-Garcia C, Bartlett DA, Zhao PA, Washburn BK, Nora EP, Kraft K, Mundlos S, Bruneau BG, Ljungman M, Fraser P, Ay F \& Gilbert DM (2019) Identifying cis Elements for Spatiotemporal Control of Mammalian DNA Replication Cell 176:816-30. [https://doi.org/10.1016/j.cell.2018.11.036 PMID: 30595451]

182. Cadoret JC, Meisch F, Hassan-Zadeh V, Luyten I, Guillet C, Duret L, Quesneville H \& Prioleau MN (2008) Genome-wide studies highlight indirect links between human replication origins and gene regulation Proc. Natl. Acad. Sci. U.S.A. 105:15837-42 [https://doi.org/10.1073/pnas.0805208105 PMID: 18838675]

183. Gros J, Kumar C, Lynch G, Yadav T, Whitehouse I \& Remus D (2015) Post-licensing Specification of Eukaryotic Replication Origins by Facilitated Mcm2-7 Sliding along DNA Mol. Cell 60:797-807 [https://doi.org/10.1016/j.molcel.2015.10.022 PMID: 26656162]

184. Letessier A, Millot GA, Koundrioukoff S, Lachagès AM, Vogt N, Hansen RS, Malfoy B, Brison O \& Debatisse M (2011) Cell-type-specific replication initiation programs set fragility of the FRA3B fragile site Nature 470:120-3 [https://doi.org/10.1038/nature09745 PMID: 21258320]

185. Smith OK, Kim R, Fu H, Martin MM, Lin CM, Utani K, Zhang Y, Marks AB, Lalande M, Chamberlain S, Libbrecht MW, Bouhassira EE, Ryan MC, Noble WS \& Aladjem MI (2016) Distinct epigenetic features of differentiation-regulated replication origins Epigenetics Chromatin 9:18 [https://doi.org/10.1186/ s13072-016-0067-3 PMID: 27168766] 
186. Sher N, Bell GW, Li S, Nordman J, Eng T, Eaton ML, Macalpine DM \& Orr-Weaver TL (2012) Developmental control of gene copy number by repression of replication initiation and fork progression Genome Res. 22:64-75 [https://doi.org/10.1101/gr.126003.111 PMID: 22090375]

187. Comoglio F, Schlumpf T, Schmid V, Rohs R, Beisel C \& Paro R (2015) High-resolution profiling of Drosophila replication start sites reveals a DNA shape and chromatin signature of metazoan origins Cell Rep 11:821-34 [https://doi.org/10.1016/j.celrep.2015.03.070 PMID: 25921534]

188. Calvi BR, Lilly MA \& Spradling AC (1998) Cell cycle control of chorion gene amplification Genes Dev. 12:734-44 [https://doi.org/10.1101/gad.12.5.734 PMID: 9499407]

189. Mosig G (1998) Recombination and recombination-dependent DNA replication in bacteriophage T4 Annu. Rev. Genet. 32:379-413 [https://doi.org/10.1146/annurev.genet.32.1.379 PMID: 9928485]

190. Ravoitytè B \& Wellinger RE (2017) Non-Canonical Replication Initiation: You're Fired! Genes (Basel) 8:E54 [https://doi.org/10.3390/genes8020054 PMID: 28134821]

191. Asai T, Sommer S, Bailone A \& Kogoma T (1993) Homologous recombination-dependent initiation of DNA replication from DNA damage-inducible origins in Escherichia coli EMBO J. 12:3287-95 [PMID: 8344265]

192. Lydeard JR, Jain S, Yamaguchi M \& Haber JE (2007) Break-induced replication and telomerase-independent telomere maintenance require Pol32 Nature 448:820-3 [https://doi.org/10.1038/nature06047 PMID: 17671506]

193. Dasgupta S, Masukata H \& Tomizawa J (1987) Multiple mechanisms for initiation of ColE1 DNA replication: DNA synthesis in the presence and absence of ribonuclease $\mathrm{H}$ Cell 51:1113-22 [https://doi. org/10.1016/0092-8674(87)90597-6 PMID: 2446774]

194. Stuckey R, García-Rodríguez N, Aguilera A \& Wellinger RE (2015) Role for RNA:DNA hybrids in origin-independent replication priming in a eukaryotic system Proc. Natl. Acad. Sci. U.S.A. 112:5779-84 [https://doi.org/10.1073/pnas.1501769112 PMID: 25902524]

195. Burki $F$ (2014) The eukaryotic tree of life from a global phylogenomic perspective Cold Spring Harb Perspect Biol 6:a016147 [https://doi.org/10.1101/cshperspect.a016147 PMID: 24789819]

196. Lee PH, Meng X \& Kapler GM (2015) Developmental regulation of the Tetrahymena thermophila origin recognition complex PLoS Genet. 11:e1004875 [https://doi.org/10.1371/journal.pgen.1004875 PMID: 25569357]

197. Mohammad MM, Donti TR, Sebastian Yakisich J, Smith AG \& Kapler GM (2007) Tetrahymena ORC contains a ribosomal RNA fragment that participates in rDNA origin recognition EMBO J. 26:5048-60 [https://doi.org/10.1038/sj.emboj.7601919 PMID: 18007594]

198. Donti TR, Datta S, Sandoval PY \& Kapler GM (2009) Differential targeting of Tetrahymena ORC to ribosomal DNA and non-rDNA replication origins EMBO J. 28:223-33 [https://doi.org/10.1038/emboj. 2008.282 PMID: 19153611]

199. Marques CA \& McCulloch R (2018) Conservation and Variation in Strategies for DNA Replication of Kinetoplastid Nuclear Genomes Curr. Genomics 19:98-109 [https://doi.org/10.1186/s12864-0184453-z PMID: 29491738]

200. Marques CA, Tiengwe C, Lemgruber L, Damasceno JD, Scott A, Paape D, Marcello L \& McCulloch R (2016) Diverged composition and regulation of the Trypanosoma brucei origin recognition complex that mediates DNA replication initiation Nucleic Acids Res. 44:4763-84 [https://doi.org/10.1093/nar/ gkw147 PMID: 26951375]

201. Tiengwe C, Marcello L, Farr H, Gadelha C, Burchmore R, Barry JD, Bell SD \& McCulloch R (2012) Identification of ORC1/CDC6-interacting factors in Trypanosoma brucei reveals critical features of origin recognition complex architecture PLoS ONE 7:e32674 [https://doi.org/10.1371/journal.pone. 0032674 PMID: 22412905]

202. Marques CA, Dickens NJ, Paape D, Campbell SJ \& McCulloch R (2015) Genome-wide mapping reveals single-origin chromosome replication in Leishmania, a eukaryotic microbe Genome Biol. 16:230 [https://doi.org/10.1186/s13059-015-0788-9 PMID: 26481451] 